\title{
Biogeochemistry
}

May 2013, Volume 113, Issue 1-3, Pages 481-505

http://dx.doi.org/10.1007/s10533-012-9778-0

(c) Springer Science+Business Media B.V. 2012

\section{Large-scale patterns of river inputs in southwestern Europe: seasonal and interannual variations and potential eutrophication effects at the coastal zone}

\author{
Estela Romero ${ }^{1,{ }^{*}}$, Josette Garnier ${ }^{1,{ }^{*}}$, Luis Lassaletta ${ }^{1}$, Gilles Billen ${ }^{1}$, Romain Le Gendre ${ }^{2}$, Philippe \\ Riou $^{2}$ and Philippe Cugier ${ }^{3}$
}

\footnotetext{
${ }^{1}$ UMR 7619 Sisyphe, CNRS-Université Pierre et Marie Curie, 75005 Paris, France

${ }^{2}$ Laboratoire Environnement et Ressources de Normandie, IFREMER, 14520 Port en Bessin, France

3 Département Dynamiques de l'Environnement Côtier, Laboratoire d'Ecologie Benthique, IFREMER, 29280 Plouzané, France
}

* : Corresponding authors : Estela Romero, email address : estela.romero@upmc.fr ;
Josette Garnier, email address : josette.garnier@upmc.fr ;

luis.lassaletta@upmc.fr ; gilles.billen@upmc.fr ; romain.le.gendre@ifremer.fr ; philippe.riou@ifremer.fr ; philippe.cugier@ifremer.fr

\begin{abstract}
:
We provide data on nutrient export for 28 rivers in southwestern Europe and analyze long-term changes in the context of anthropogenic pressures and regulation policies. Special attention is given to seasonal variations, because the integrated annual values that are usually provided do not allow us to establish comparisons with seasonal phytoplankton dynamics. The eutrophication risk associated with river inputs is addressed by means of an indicator (Index of Coastal Eutrophication Potential, ICEP, Billen and Garnier, Mar Chem 106:148-160, 2007). An overview of the temporal evolution and the intra-annual variability of the ICEP is discussed for specific rivers and integrated coastal regions. The annual dynamics of the eutrophication indicator is analyzed to delimit those periods when the risk of eutrophication is particularly high. The trends in nutrient fluxes and coastal phytoplankton are compared by means of a case study (Seine Bay). The decrease in phosphorus matches a general decrease in phytoplankton biomass in the summer. However, sustained high values of nitrogen still foster the emergence of harmful algal blooms, and we found an increase in the summer abundance of dinoflagellates. The abatement of phosphorus alone is not enough to shortcut harmful blooms and toxic outbreaks in the Seine Bay. A reduction in nitrogen inputs may be necessary to effectively minimize eutrophication problems.
\end{abstract}

Keywords: River inputs ; Coastal zone ; N:P:Si stoichiometry ; Eutrophication ; Seasonality ; Europe 


\section{INTRODUCTION}

Coastal areas play a fundamental role in the functioning of marine ecosystems. These are strategic, transitional areas in which terrestrial and oceanic factors come together, whose dynamics determines a wide variety of natural resources. River inputs are among the major physical drivers of coastal dynamics. Apart from their effects on buoyancy and vertical stratification, land-derived fresh waters carry inorganic and organic compounds that can trigger the growth of marine organisms. This natural supply of nutrients by rivers, however, has dramatically increased in the last few decades as a consequence of various factors, notably the extensive use of mineral fertilizers in agriculture and the step-up of urban pressure along the coast (EEA 2005 and 2010). The cumulative effects of global change, including climate change, increased population, and more intense industrialization and agribusiness will likely magnify the pressure in estuarine and coastal waters (Rabalais et al. 2009).

Sustained nutrient overload can lead to the emergence of eutrophic coastal waters and result in a series of undesirable effects. Nutrients spur the growth of phytoplankton, and excessive algal growth increases the amount of organic matter settling to the bottom (Jørgensen \& Richardson 1996; Cloern 2001). In turn, high concentrations of organic matter increase oxygen consumption, which may eventually cause oxygen depletion of bottom waters and drive drastic changes in community structure or death of the benthic fauna (Conley et al. 2007; Diaz \& Rosenberg 2008). Further, nutrient excess can promote the risk of harmful algal blooms (HABs) that cause seawater discoloration, foams, death of fish and benthic fauna, or shellfish poisoning of humans (e.g., Montresor \& Smetacek 2002). Besides the oversupply of nutrients, at the core of many eutrophication problems, disturbances can also be linked to changes in the relative composition of nutrients. Changes in the N:P and Si:N ratios can induce shifts within the plankton assemblages, favoring the dominance of specific groups of plankton and ultimately fostering the emergence of algal blooms (Officer \& Ryther 1980; Smayda 1990; J ustić et al. 1995; Billen \& Garnier 2007).

River fluxes have largely evolved in western European countries since the beginning of the 20th century. Inputs closely follow changes in neighboring human activities, and three phases can be broadly distinguished: an early stage of nearly pristine/ undisturbed waters, with scarce or inexistent nutrient excesses, a second phase of very high nutrient loads, and a later period of stabilization and/or partial reduction of inputs (EEA 2001). Time boundaries between these three stages differ among European regions, as do the rates of change and the apportionment of nutrients.

Previous studies assessing long-term changes in freshwater quality (Bouraoui \& Grizzetti 2011) and official reports on eutrophication issues in European waters (e.g., EEA 2001 and 2002; OSPAR 2003) 
have mostly focused on annual nutrient concentrations and average yearly or winter fluxes. This approach is clearly useful to describe large temporal variations, but it may be insufficient to assess further impacts on the marine ecosystem. At best, winter concentrations signal the magnitude of the annual chlorophyll peak, but they do not provide any information on summer trends, the time when numerous noxious episodes take place.

The present work aims to fill in some gaps in the study of eutrophication in European coastal waters. First, we focus on a geographical area (southwestern Europe) where large-scale, comparative studies are less abundant than in other parts of Europe, such as the North Sea or the Baltic Sea. River quality monitoring programs started somewhat later in many parts of southwestern Europe and therefore, until recently, studies were limited by the few data available (e.g., EEA 2001). Second, even though coastal dynamics are tightly constrained by seasonal features, intra-annual changes in river inputs are seldom analyzed. Further insights into seasonal variations in river discharge and related nutrient fluxes may provide a better understanding of their influence on coastal phytoplankton. Third, we pay particular attention to the relative proportion of nutrient elements in freshwater inflows, and specifically to the content of silica $(\mathrm{Si})$ in relation to nitrogen $(\mathrm{N})$ and phosphorus $(\mathrm{P})$. Unlike $\mathrm{N}$ and $\mathrm{P}$, the $\mathrm{Si}$ concentration in the water is mainly linked to natural processes of rock weathering and erosion and the influence of anthropogenic activities is limited (as evidenced, for instance, in the Seine River by Sferratore et al. 2006; Garnier et al. 2006). Nonetheless, the silicic load of rivers can be affected by dams (through increased retention) and by increased loading of $\mathrm{N}$ and $\mathrm{P}$, because nutrient enrichments enhance production, and thus sedimentation, of diatoms in reservoirs and along the river continuum (Conley et al. 1993; Humborg et al. 2006; Garnier et al. 2010 and references therein). As a result, the ratios of N:Si and P:Si have greatly changed over the past decades. The relative scarcity of silica can be related to shifts between phytoplankton groups, notably with the substitution of diatoms by other plankton algae that do not have silica requirements, such as flagellates and dinoflagellates. Besides the fact that some of these organisms are HAB-forming species, this type of change in the community structure has many implications in terms of biogeochemical cycles (Humborg et al. 2000; reviews by Anderson et al. 2002; Glibert et al. 2010).

Our main objectives are: (i) to provide an overview of river inputs in southwestern Europe from the 1990s to the present, with a special emphasis on seasonal variability and differences between coastal fronts; (ii) to assess major changes in the proportion of N, P and $\mathrm{Si}$ and, on this basis, calculate an Index of Coastal Eutrophication Potential (ICEP, Billen \& Garnier 2007); (iii) to compare, by means of a case study (Seine Bay), whether temporal trends in the eutrophication index match changes in coastal phytoplankton. 


\section{MATERIALS \&METHODS}

\subsection{River Databases}

Data used in the present study were obtained from several water authorities and hydrographic confederations in France, Italy, Spain, Portugal and Belgium. We have compiled the most recent information available on four different coastal fronts: the Atlantic coasts of Portugal and France, the eastern part of the English Channel (France, Belgium), the western Mediterranean coast (Spain, France, Italy) and the northern Adriatic coast (Italy). Beyond the difference in climatological and biophysical characteristics, these coastal fronts encompass a group of European regions with different socioeconomic features (Metzger et al. 2010) that are very interesting to compare within the context of nutrient fluxes. Table 1 specifies the data source, available time period and the catchment area of all the rivers included in the study.

In order to accurately assess freshwater fluxes and their associated nutrient inputs, we systematically selected those gauging stations that are located close to the river mouth and specifically those where nutrient concentrations are regularly measured. When information on water quality was not available for the same location, we used data from the nearest station representative of the river's outlet (e.g., no major tributaries located downstream from the selected station). Water quality data sets consisted mostly of monthly measurements and were rather heterogeneous across different river basins: a large set of chemical and biological parameters was available for some stations, but scarce or very short time series existed for others, such as for some of the Italian catchments. Roughly, we used a basic set of quality parameters that comprised data on inorganic macronutrients (i.e., phosphate, nitrate, nitrite, ammonium and silicate), total phosphorus (TP), total nitrogen (TN) and freshwater chlorophyll.

When the time series of TP was shorter than that of $\mathrm{PO}_{4}^{3-}$ we fitted a linear regression between the two variables, specific for each river. Provided that the regression model fitted the data well, we applied the resulting equation to fill in the gaps of the TP data series. When no data on total phosphorus was available, the concentration of total phosphorus was calculated from phosphate concentrations applying the formula in Garnier et al. (2010), calculated for a global database. Interestingly, when plotting together all data used to calculate the specific regressions between TP and $\mathrm{PO}_{4}{ }^{3^{-}}$we obtained the equation: $\mathrm{TP}=\left(1.57 \times \mathrm{P}^{-\mathrm{PO}_{4}{ }^{3-}}\right)+0.09\left(\mathrm{~N}=5664 ; \mathrm{R}^{2}=0.49 ; \mathrm{p}<0.001\right)$, very close to that obtained by Garnier et al. (2010) for an extensive group of world rivers (TP $=(1.5 \times \mathrm{P}$ $\left.\mathrm{PO}_{4}{ }^{3-}\right)+0.1$. 
Table 1. Data source, catchment area and available time period for each of the rivers included in the study.

\begin{tabular}{|c|c|c|c|c|c|}
\hline \multirow{2}{*}{ Coastal front } & \multirow{2}{*}{ River } & \multirow{2}{*}{$\begin{array}{l}\text { Catchment } \\
\text { area }\left(\mathbf{k m}^{2}\right)\end{array}$} & \multirow{2}{*}{ Data source } & \multicolumn{2}{|c|}{ Time period } \\
\hline & & & & River flow & Quality \\
\hline \multirow{4}{*}{ English Channel } & Scheldt & 21860 & International Scheldt Commission (www.isc-cie.org), VMM (www.vmm.be) & $1990-2005$ & $1977-2008$ \\
\hline & Somme & 6223 & Eau France - MEDD (www.eaufrance.fr) & $1970-2010$ & $1970-2010$ \\
\hline & Seine & 75989 & Eau France - MEDD (www.eaufrance.fr) & $1985-2007$ & $1985-2009$ \\
\hline & Orne & 2948 & Eau France - MEDD (www.eaufrance.fr) & $1984-2010$ & $1985-2009$ \\
\hline \multirow{6}{*}{ Atlantic (France) } & Aulne & 1687 & Eau France - MEDD (www.eaufrance.fr) & $1976-2010$ & $1979-2010$ \\
\hline & Vilaine & 10490 & Eau France - MEDD (www.eaufrance.fr) & $1970-2010$ & $1976-2010$ \\
\hline & Loire & 116981 & Eau France - MEDD (www.eaufrance.fr) & $1971-2010$ & $1976-2010$ \\
\hline & Dordogne & 23902 & Eau France - MEDD (www.eaufrance.fr) & $1971-2010$ & $1997-2009$ \\
\hline & Garonne & 55703 & Eau France - MEDD (www.eaufrance.fr) & $1989-2010$ & 1971-2009 \\
\hline & Adour & 16861 & Eau France - MEDD (www.eaufrance.fr) & $1970-2010$ & 1992-2009 \\
\hline Atlantic (Portugal) & Douro & 97682 & SNIRH (http:// snirh.inag.pt/ ) & $1990-2010$ & $1990-2010$ \\
\hline \multirow{13}{*}{ W Mediterranean } & Segura & 19525 & CEDEX (http:// hercules.cedex.es), CH Segura (www.chsegura.es) & $1990-2010$ & $1997-2010$ \\
\hline & Jucar & 21578 & CEDEX (http:// hercules.cedex.es), CH J ucar (www.chj.es) & $1990-2010$ & $1990-2009$ \\
\hline & Ebro & 85000 & CEDEX (http:// hercules.cedex.es), CH Ebro (www.chebro.es) & $1980-2008$ & $1981-2008$ \\
\hline & Aude & 5226 & Eau France - MEDD (www.eaufrance.fr) & $1987-2010$ & $1986-2010$ \\
\hline & Orb & 1556 & Eau France - MEDD (www.eaufrance.fr) & $1966-2010$ & $1981-2010$ \\
\hline & Herault & 2625 & Eau France - MEDD (www.eaufrance.fr) & $1971-2010$ & $1976-2010$ \\
\hline & Vidourle & 827 & Eau France - MEDD (www.eaufrance.fr) & $1969-2010$ & $1981-2010$ \\
\hline & Rhone & 96619 & Eau France - MEDD (www.eaufrance.fr) & $1987-2009$ & $1987-2010$ \\
\hline & Touloubre & 1576 & Eau France - MEDD (www.eaufrance.fr) & $1997-2010$ & $1988-2010$ \\
\hline & Gapeau & 566 & Eau France - MEDD (www.eaufrance.fr) & $1961-2010$ & $1985-2010$ \\
\hline & Argens & 2762 & Eau France - MEDD (www.eaufrance.fr) & $1971-2010$ & $1971-2010$ \\
\hline & Arno & 8228 & IDROPISA (www.idropisa.it), SIRA TOSCANA (http:// sira.arpat.toscana.it/ sira) & 1990-2009 & $1997-2009$ \\
\hline & Tiber & 17375 & UIM (www.idrografico.roma.it), ARPA LAZIO (www.arpalazio.net) & $2000-2010$ & 2005-2007 \\
\hline NAdriatic & Po & 71057 & ADB PO (www.adbpo.it), ARPA EMILIA-ROMAGNA (www.arpa.emr.it) & $1990-2008$ & $2003-2010$ \\
\hline
\end{tabular}


TN values were calculated as the sum of $\mathrm{N}^{-\mathrm{NO}_{3}}{ }^{-}, \mathrm{N}^{-\mathrm{NO}_{2}}{ }^{-}$and $\mathrm{N}$ Kjeldahl; when the latter was not provided, we used the formula in Garnier et al. (2010), which determines TN from the concentration of $\mathrm{N}-\mathrm{NO}_{3}{ }^{-}$according to the following relationship: $\mathrm{TN}=\left(1.2 \times \mathrm{N}^{-} \mathrm{NO}_{3}{ }^{-}\right)+0.1$. In those rivers for which the data set was complete, we tested whether estimates of TN using the formula by Garnier et al. (2010) matched the actual concentration of TN measured in the water. We found that, in general, estimates based on nitrate concentrations slightly underestimated the amount of total nitrogen. This was particularly severe in a few French Mediterranean rivers, where calculated values could be ca. $30 \%$ lower than measured concentrations (i.e., in those catchments with little agricultural land and where $\mathrm{N}$ inputs were mostly related to urban sewage). Overall, concentrations of TN obtained with the equation in Garnier et al. (2010) accounted for approximately 90\% of measured TN concentrations on the Atlantic coast and were somewhat lower ( 75- 85\%) for the Mediterranean littoral.

Until recently, the concentration of silicate was not routinely measured in many monitoring programs and thus the time series provided were often limited to a few years. In those cases, we used the available measurements to calculate the concentration of silicate during an average year. Monthly values from this average year were then used to complete the time series. When there was no information whatsoever on the concentration of silica (4 rivers: Dordogne, Po, Arno and Jucar), we

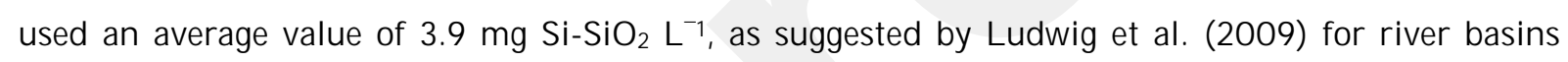
within the $12-20^{\circ} \mathrm{C}$ temperature range. Table 2 shows the average concentration of silicate for the 28 rivers in the study. The silicic load of rivers can be affected by dams and by increased in-stream consumption due to concomitant high concentrations of N and P. Dam construction took place mostly before the 1990s on European rivers, so no substantial changes with regard to dam retention are to be expected during the study period. On the other hand, some variations related to river eutrophication might have occurred. Most of the Si data used to calculate average monthly concentrations come from recent surveys and correspond to a period of low or medium nutrient inputs with respect to the previous years (with a few exceptions). If Si depletion due to river eutrophication was substantial, then our inferred values of $\mathrm{Si}$ concentration would be higher than the actual ones and the P:Si and N:Si ratios would be underestimated. Data on freshwater chlorophyll provides an ancillary tool to evaluate the importance of river eutrophication and the corresponding silica depletion along the river continuum.

\subsection{Nutrient fluxes}

Nutrient fluxes were calculated as the product of monthly concentrations of TP, TN and $\mathrm{Si}$, and monthly accumulated flow. River discharge is most frequently provided in the form of average daily flow $\left(\mathrm{m}^{3} \mathrm{~s}^{-1}\right)$, so we calculated accumulated daily discharges $\left(\mathrm{m}^{3} \mathrm{~d}^{-1}\right)$ and then obtained the monthly 
Table 2. Average annual ( \pm standard deviation) and seasonal silicate concentration for the 28 rivers in the study during all available years. S stands for summer (May- Oct) and W for winter (Nov-April). For those rivers that did not have documented silica measurements (Dordogne, Po, Arno and J ucar), an average value of $3.9 \mathrm{mg}$ $\mathrm{Si}-\mathrm{SiO} 2 \mathrm{~L}^{-1}$ was considered according to Ludwig et al. (2009).

\begin{tabular}{|c|c|c|c|}
\hline Si-SiO2 $\left(\mathrm{mg} \mathrm{L}^{-1}\right)$ & All year & $\mathbf{S}$ & $\mathbf{W}$ \\
\hline Scheldt & $2.21 \pm 0.86$ & 1.67 & 2.75 \\
\hline Somme & $3.66 \pm 0.65$ & 3.61 & 3.71 \\
\hline Seine & $3.06 \pm 1.10$ & 2.69 & 3.43 \\
\hline Orne & $4.30 \pm 0.82$ & 4.27 & 4.33 \\
\hline Aulne & $3.21 \pm 1.13$ & 2.60 & 3.81 \\
\hline Blavet & $4.07 \pm 1.23$ & 3.53 & 4.60 \\
\hline Vilaine & $3.04 \pm 1.17$ & 2.32 & 3.76 \\
\hline Loire & $4.28 \pm 1.41$ & 3.38 & 5.19 \\
\hline Dordogne & $3.90 \pm 2.20$ & 3.90 & 3.90 \\
\hline Garonne & $2.50 \pm 0.55$ & 2.29 & 2.73 \\
\hline Adour & $2.26 \pm 0.31$ & 2.29 & 2.23 \\
\hline Douro & $1.63 \pm 1.27$ & 0.36 & 2.89 \\
\hline Tagus & $4.46 \pm 1.14$ & 4.20 & 4.72 \\
\hline Segura & $5.08 \pm 1.86$ & 4.11 & 6.03 \\
\hline Jucar & $3.90 \pm 2.20$ & 3.90 & 3.90 \\
\hline Ebro & $1.96 \pm 0.64$ & 1.73 & 2.20 \\
\hline Aude & $3.15 \pm 1.14$ & 4.00 & 2.31 \\
\hline Orb & $2.79 \pm 0.73$ & 3.17 & 2.41 \\
\hline Herault & $2.87 \pm 0.54$ & 3.27 & 2.48 \\
\hline Vidourle & $3.00 \pm 0.93$ & 2.97 & 3.03 \\
\hline Rhone & $2.64 \pm 0.43$ & 2.28 & 3.00 \\
\hline Touloubre & $4.15 \pm 0.79$ & 3.51 & 4.79 \\
\hline Gapeau & $4.22 \pm 0.89$ & 4.47 & 3.98 \\
\hline Argens & $4.09 \pm 0.66$ & 4.06 & 4.12 \\
\hline Arno & $3.90 \pm 2.20$ & 3.90 & 3.90 \\
\hline Tiber & $3.02 \pm 1.29$ & 2.39 & 3.65 \\
\hline Po & $3.90 \pm 2.20$ & 3.90 & 3.90 \\
\hline Adige & $1.50 \pm 0.81$ & 1.36 & 1.63 \\
\hline
\end{tabular}


river flow as the sum of daily values. Further, to allow comparisons between different river basins, nutrient fluxes were re-scaled per square kilometer, dividing the flux by the area of the corresponding catchment.

We compared the nutrient fluxes thus obtained with those calculated using flow-adjusted concentrations, as described by Verhoff et al. (1980) and recommended by Walling \& Webb (1985). We applied the formula:

$$
\mathrm{N} \text { flux }=\mathrm{Q}_{\mathrm{m}} \cdot\left(\mathrm{K} \cdot \Sigma\left(\mathrm{C}_{\mathrm{i}} \cdot \mathrm{Q}_{\mathrm{i}}\right) / \Sigma \mathrm{Q}_{\mathrm{i}}\right)
$$

where $\mathrm{K}$ is the conversion factor to take the recorded period into account (e.g., 365 days), $\mathrm{C}_{\mathrm{i}}$ the instantaneous concentration, $\mathrm{Q}_{\mathrm{i}}$ the corresponding instantaneous water flow, and $\mathrm{Q}_{\mathrm{m}}$ the mean water flow for the period considered (annual, summer or winter). Flow-adjusted concentrations are commonly used when assessing annual fluxes, e.g., for the Seine River (Némery et al. 2005) or, more generally, in the commission guidelines of the OSPAR Convention (Convention for the Protection of the marine Environment of the North-East Atlantic, OSPAR 1998), but they are not valid when estimating monthly inputs because quality monitoring programs typically conduct just one sampling per month. Nonetheless, we examined whether our annual values tallied with those obtained applying the equation above and found a very good correspondence between them $\left(R^{2}=0.97,<10 \%\right.$ difference for most rivers).

\subsection{Index of Coastal Eutrophication Potential}

The ICEP is a synthetic indicator proposed by Billen \& Garnier (2007) to assess the potential of river systems for coastal eutrophication. Briefly, the index considers (after several authors; see Billen \& Garnier 2007 and references therein) that many coastal eutrophication problems are the consequence of the new production of non-siliceous algae sustained by nitrogen and phosphorus delivered in excess over dissolved silica, with regard to the requirements for diatom growth. Accordingly, it represents the carbon biomass potentially produced in a coastal water body through new production sustained by the riverine flux of $\mathrm{N}$ or $\mathrm{P}$ delivered in excess over Si. It is based on the Redfield molar C:N:P:Si ratios (106:16:1:20, Redfield 1934; Redfield et al. 1963) and can be calculated by the equation:

$$
\begin{aligned}
& \operatorname{ICEP}(\mathrm{N})=\left[\mathrm{N}_{\mathrm{Flx}} /(14 \times 16)-\mathrm{Si}_{\mathrm{Flx}} /(28 \times 20)\right] \times 106 \times 12 \\
& \operatorname{ICEP}(\mathrm{P})=\left[\mathrm{P}_{\mathrm{Flx}} /(31 \times 1)-\mathrm{Si}_{\mathrm{Flx}} /(28 \times 20)\right] \times 106 \times 12
\end{aligned}
$$

where $\mathrm{P}_{\mathrm{Flx}}, \mathrm{N}_{\mathrm{Flx}}$ and $\mathrm{Si}_{\mathrm{Flx}}$ are, respectively, the mean specific fluxes of total nitrogen, total phosphorus and dissolved silica delivered at the outlet of the river basin, expressed in $\mathrm{kg} \mathrm{P} \mathrm{km}^{-2}$ day-1, in $\mathrm{kg} \mathrm{N} \mathrm{km}^{-2}$ day-1 and in $\mathrm{kg} \mathrm{Si} \mathrm{km}^{-2}$ day-1. The ICEP is thus formulated in units of $\mathrm{kg} \mathrm{C} \mathrm{km}^{-2}$ day-1, i.e., carbon per 
day, as is common for marine primary production, and by units of watershed area, to allow comparisons between rivers. Broadly, a positive value of the ICEP indicates an excess of nitrogen or phosphorus over the requirements for diatom growth, hence a favorable condition for the development of harmful non-siliceous algae. Negative values indicate that silica is present in excess over $\mathrm{N}$ and $\mathrm{P}$ and thus, on the basis of our view, less risk of eutrophication. Note that the index does not take into account specific features of the receiving coastal waters, but simply represents the potential eutrophication impact of river inputs.

Unlike previous studies by Billen \& Garnier (2007) for the Seine River and by Garnier et al. (2010) for a group of world rivers, here we do not examine annual fluxes but rather assess intra-annual, seasonal variations. Seasonality is of great importance both in relation to river flow regimes and to investigate the response of plankton, as the dynamics of planktonic organisms is naturally constrained by seasonal features (light availability and water column mixing, for instance). Accordingly, in addition to analyzing the monthly dynamics we obtained seasonal index values by grouping the original data into two categories: a winter period (November to April) and a summer one (May to October).

Further, both P-ICEP and N-ICEP were considered. The growth of phytoplankton may be alternatively limited by $\mathrm{P}$ or $\mathrm{N}$ depending on the N:P ratio of available nutrients. The lowest value between N-ICEP and P-ICEP should therefore be taken into account (Garnier et al. 2010). However, as argued by Garnier et al. (2010), owing to the high biochemical adaptation capacity of phytoplankton to low phosphate availability (induction of algal phosphatase), P may be actively and rapidly remobilized in marine waters (bacterial and zooplankton mineralization) where nutrient stocks are usually above the Redfield ratio. Additionally, the ratio of $\mathrm{N}$ to $\mathrm{P}$ may vary largely throughout the year and thus when elucidating seasonal patterns, it is convenient to consider both indicators.

\subsection{Coastal phytoplankton data}

To go further, we have examined whether changes in nutrient fluxes and the variations observed in the index of eutrophication potential match changes in coastal phytoplankton biomass. Very detailed data on phytoplankton could be obtained for the Seine Bay, in northwestern France. This area is particularly valuable for a number of reasons: it is a regularly sampled site, it is representative of a highly anthropogenically disturbed environment (Billen et al. 2001) and the nutrient fluxes are among the highest ones within our study. Data on phytoplankton biomass along the Normandy coast, including the Seine Bay, were from the French RHLN network and were kindly provided by the IFREMER (French Research Institute for Exploration of the Sea). Detailed information on phytoplankton species came from the REPHY monitoring program and was also furnished by the IFREMER. 


\subsection{Statistical analyses}

We split the data into several 5-year periods in order to examine whether there have been significant changes in river flow, nutrient fluxes and freshwater chlorophyll during the past two decades. We consider that 5-year intervals are useful to detect average changes and temporal trends, because a 5-year period includes dry and wet years, and therefore the minimum and maximum flow values are considered. Time series for some rivers were unavailable or incomplete before the 1990s, and corrected, revised records were not always accessible after 2007 (see Table 1). Taking into account the available data, we decided to select two distinct periods: 1991- 1995 and 2001- 2005. The time lag may bring out the effects of environmental policies in Europe (cf. the Water Framework Directive, Directive 2000/60/EC), which have evolved tremendously over the last decade, and the improvements in wastewater treatment technologies, which for the most part were not available during the early 1990s. Differences between time periods were assessed by means of nonparametric Mann-Whitney U tests.

Beyond the decadal change, we were interested in assessing the seasonal characteristics and the temporal evolution of the ICEP indicators, and the parallel trends in coastal phytoplankton. We used the nonparametric Seasonal Kendall test (SK test, Hirsch et al. 1982), because this is a very powerful tool used to analyze temporal trends taking into account seasonal variations. SK tests were applied to P-ICEP, N-ICEP, and to the case-study marine phytoplankton data, including chlorophyll a, total microphytoplankton, diatoms, dinoflagellates and the concentration of a few potentially toxic species. The SK test was performed to detect significant monotonic trends; it can be used for time series of data with seasonal variations, missing values, tied values, or values below the limit of detection, and does not require data normality (Yu et al. 1993; Lassaletta et al. 2009). The SK test applies the MannKendall test to each season separately, and then combines these results in an overall statistic. All SK tests were performed with an MS Excel ${ }^{\circledR}$ tool developed by Libiseller (2004). The significance level was set at 0.05 except for the trend analysis, where we used $\mathrm{p}<0.10$ (as is commonly used in nonparametric analyses when data vary greatly, Yu et al. 1993; Hodgkins \& Dudley 2006). Statistica (StatSoft Inc., Tulsa, OK, USA) was used to compute the Mann-Whitney U tests and other statistical analyses.

\section{RESULTS}

\subsection{River flow characterization}

\subsubsection{Annual flow regime}


A good characterization of the annual flow regime is an important factor to be considered because the dynamics of nutrients and pollutants that are mainly transferred through diffuse sources is directly related to changes in the river flow, and because it exerts a dilution effect on those compounds coming from point sources. For most rivers, we have gathered daily flow data over at least 15 years (for the 1990- 2005 period; see Table 1), including dry and wet conditions.

In most cases the winter season, in this study the period between November and April, concentrates over two-thirds of the annual river flow (on average $72 \%$ of the total annual discharge). This asymmetry is particularly pronounced in the small streams of the Atlantic coast, such as the Sevre-Niortaise, Lay, Falleron or the Aulne rivers, where winter flow can account for over $85 \%$ of the annual discharge (Table 3). In contrast, there are some highly regulated rivers where summer flow can be as high as winter flow (notably on the southern Mediterranean coast, e.g., the Jucar, where droughts are a climatic feature and flow regulation is common practice) or rivers where the base flow is naturally high and water discharge is more evenly distributed throughout the year (e.g., the Somme, the Rhone and the Po rivers).

Interannual differences in river flow related to dry or wet conditions are also remarkable: in the largest rivers, such as the Rhone, the Po and the Loire rivers, maximum fluctuations are about $\pm 50 \%$, but the range of variation increases in medium and small streams, for which we can find steep decreases (-80\% in the J ucar, Vidourle and Gapeau) and huge increases, sometimes two- or threefold the flow of an average year (e.g., the Herault, Argens, Vilaine, Somme, Seine and Douro).

\subsubsection{Geographical distribution of freshwater inputs: contribution of each river to the total}

Although not all existing rivers are included in the study, we have managed to obtain data from the largest catchments in each of the four coastal fronts examined; we can hence provide a good overall description on riverine fluxes to their adjacent coastal zones.

In the western Mediterranean basin, the Rhone River is clearly the chief contributor to freshwater fluxes and is responsible for approximately $70 \%$ of the total inputs analyzed. The Ebro River (NE Spain) and the Tiber River (Italy) are the next two largest streams studied, with $12 \%$ and $7 \%$ of the total inputs, respectively (Table 3). Two rivers were studied in the northern Adriatic, the Po and the Adige; the Po River is plainly the major stream in the region and one of the largest rivers in southern Europe (only after the Rhone), and therefore a dominant forcing factor in the nearby coastal area. In the eastern English Channel and on the Atlantic coast of France, freshwater inputs are more regularly distributed across the territory: the Loire and the Seine rivers make up ca. 50\% of the total inflows, but the Garonne, Adour and Dordogne rivers also have a significant share (about 10-17\% each). The 
Table 3. Average annual ( \pm standard deviation) and seasonal river flow $\left(\mathrm{Hm}^{3} \mathrm{y}^{-1}\right)$ for the $1990-2010$ period. S stands for summer (May- Oct) and W for winter (Nov- April).

\begin{tabular}{|c|c|c|c|c|c|c|c|c|c|c|c|c|c|c|}
\hline & & Annual & $\mathrm{S}$ & $\mathrm{W}$ & & & Annual & $\mathrm{S}$ & $\mathrm{W}$ & & & Annual & $\mathrm{S}$ & W \\
\hline \multirow{20}{*}{$\begin{array}{l}\text { ENG. } \\
\text { CHANNEL }\end{array}$} & Scheldt & $4399 \pm 1309$ & 1426 & 2973 & \multirow{18}{*}{$\begin{array}{l}\text { ATLANTIC } \\
\text { (FR) }\end{array}$} & Leguer & $196 \pm 56$ & 41 & 157 & \multirow[t]{18}{*}{ W MEDIT. } & Segura & $7 \pm 10$ & 1 & 5 \\
\hline & Somme & $1119 \pm 423$ & 485 & 630 & & Aulne & $774 \pm 200$ & 124 & 650 & & Jucar & $638 \pm 281$ & 344 & 300 \\
\hline & Bresle & $230 \pm 63$ & 105 & 124 & & Odet & $150 \pm 43$ & 29 & 121 & & Ebro & $8746 \pm 2797$ & 2816 & 5930 \\
\hline & Seine & $17560 \pm 6175$ & 5623 & 11937 & & Laïta & $472 \pm 134$ & 103 & 369 & & Agly & $179 \pm 136$ & 46 & 133 \\
\hline & Touques & $161 \pm 40$ & 65 & 96 & & Scorff & $162 \pm 45$ & 35 & 127 & & Aude & $1028 \pm 491$ & 299 & 729 \\
\hline & Dives & $257 \pm 114$ & 79 & 179 & & Blavet & $851 \pm 262$ & 185 & 666 & & Orb & $739 \pm 408$ & 193 & 547 \\
\hline & Orne & $887 \pm 350$ & 231 & 654 & & Vilaine & $2349 \pm 1114$ & 403 & 1958 & & Herault & $1094 \pm 652$ & 315 & 786 \\
\hline & Seulles & $80 \pm 31$ & 18 & 62 & & Loire & $26633 \pm 8246$ & 7051 & 19582 & & Lez & $95 \pm 33$ & 26 & 66 \\
\hline & Aure & $199 \pm 66$ & 38 & 161 & & Falleron & $37 \pm 17$ & 4 & 33 & & Vidourle & $253 \pm 146$ & 73 & 172 \\
\hline & Vire & $496 \pm 176$ & 87 & 401 & & Lay & $427 \pm 91$ & 38 & 388 & & Vistre & $117 \pm 41$ & 44 & 73 \\
\hline & Taute & $109 \pm 33$ & 26 & 83 & & Sevre Niort. & $404 \pm 100$ & 61 & 342 & & Rhone & $52284 \pm 9207$ & 21213 & 31072 \\
\hline & Douve & $508 \pm 152$ & 108 & 400 & & Seudre & $40 \pm 8$ & 11 & 29 & & Touloubre & $83 \pm 11$ & 50 & 33 \\
\hline & Sienne & $266 \pm 107$ & 56 & 210 & & Livenne & $79 \pm 20$ & 15 & 63 & & Huveaunne & $32 \pm 22$ & 10 & 22 \\
\hline & See & $196 \pm 73$ & 56 & 139 & & Dordogne & $8218 \pm 1927$ & 2534 & 5683 & & Gapeau & $106 \pm 66$ & 23 & 83 \\
\hline & Selune & $285 \pm 118$ & 77 & 208 & & Garonne & $16367 \pm 4504$ & 5505 & 10942 & & Argens & $482 \pm 267$ & 149 & 353 \\
\hline & Couesnon & $230 \pm 115$ & 49 & 180 & & Leyre & $489 \pm 154$ & 148 & 341 & & Arno & $2410 \pm 680$ & 585 & 1825 \\
\hline & Rance & $82 \pm 42$ & 14 & 68 & & Ste. Eulalie & $147 \pm 63$ & 31 & 116 & & Tiber & $5150 \pm 1293$ & 1984 & 3166 \\
\hline & Arguenon & $25 \pm 10$ & 4 & 21 & & Adour & $9589 \pm 1815$ & 3435 & 6151 & & & & & \\
\hline & Gouessant & $45 \pm 19$ & 8 & 37 & \multirow{2}{*}{$\begin{array}{l}\text { ATLANTIC } \\
\text { (PT) }\end{array}$} & Douro & $15602 \pm 8128$ & 3589 & 12013 & \multirow{2}{*}{$\begin{array}{l}\mathrm{N} \\
\text { ADRIATIC }\end{array}$} & Po & $45617 \pm 12613$ & 22413 & 23205 \\
\hline & Trieux & $168 \pm 50$ & 36 & 133 & & Tagus & $8835 \pm 3405$ & 1882 & 5580 & & Adige & $6691 \pm 2342$ & 2974 & 3035 \\
\hline
\end{tabular}


Douro and the Tagus are the two major streams on the Portuguese coast; the Douro River provides the largest contribution, with a flow equivalent to that of the Seine River (Table 3).

\subsubsection{Decadal comparison and seasonal variations}

In general, river flows have not undergone substantial changes and average flow values are similar for the two periods studied (Table 4, p >0.05 in most cases). Changes in river flow are closely related to climatological conditions and dry/ wet cycles, and longer periods of time may be necessary to detect significant changes (Pekarova et al. 2003; 2006). There has been, however, a short-term decrease of flow in some Mediterranean streams, namely the Segura and the Jucar, possibly because these catchments have suffered from extensive and recurrent droughts in the past few years (Andreu et al. 2009; Barceló \& Sabater 2010 and references therein) or owing to the intensive water usage and the construction of barrages for irrigation (Lehner et al. 2001; Wriedt et al. 2009). Bouraoui et al. (2010) found that no major trends appeared in the freshwater fluxes to the Mediterranean Sea between 1980 and 2000, in spite of a significant increase in temperature and a partial decrease of precipitation observed in the basin; in particular, no trends were detected in the discharge of the Rhone, the Po and the Ebro rivers. Ludwig et al. (2003, 2009) focused on a longer period (1960-2000) and found a general decrease of riverine freshwater discharge in the Mediterranean region (with the exception of the Rhone and the Po), mostly related to dryer and warmer conditions, and river damming. Conversely, wetter conditions may be the cause underlying the temporary flow increases observed around the English Channel during the last period, 2001 being particularly wet.

\subsection{Nutrient loads and Index of Coastal Eutrophication Potential}

While no critical variations have occurred in terms of river flow, conspicuous changes in nutrient load could be widely observed across Europe between the 1990s and the 2000s (Fig. 1).

Phosphorus inputs. The load of phosphorus has significantly decreased with regard to the 1990s in most European rivers (on average, -16\% in the Atlantic, -39\% in the eastern English Channel and -53\% in the Mediterranean littoral, Table 4). The highest $\mathrm{P}$ reductions have occurred in low-flow Mediterranean streams, i.e., the J ucar, the Orb and the Herault, followed by rivers in Brittany (the Vilaine, Blavet), and large rivers such as the Garonne and the Seine, where the abatement is also huge in absolute numbers (on average $~ 400-500 \mathrm{Tn}$ P.month ${ }^{-1}$ ). In accordance, there are nowadays many negative P-ICEP values found on both the Mediterranean and the Atlantic coasts (Fig. 2a), which means that, at the present time, phosphorus is limiting with regard to silicate in most river systems. Long-term monthly data were not available for the Po and the Adige rivers and decadal changes could not be assessed in the northern Adriatic, yet the index remains negative in the Po River for the 2001- 
Table 4. Average flow and nutrient fluxes for the 1991- 1995 and 2001- 2005 periods in SW European rivers. Summary of statistical results (Mann-Whitney $U$ tests) for the difference between the two 5-year periods examined. Asterisks denote significant levels where ${ }^{* * *} \mathrm{p}<0.001$, $* * \mathrm{p}<0.01, * \mathrm{p}<0.05$, n.s. (not significant) refers to $\mathrm{p}>0.05$. Arrows on the right show the increasing or decreasing trend.

\begin{tabular}{|c|c|c|c|c|c|c|c|c|c|c|c|c|}
\hline & \multicolumn{3}{|c|}{$\mathbf{Q}\left(\mathrm{Hm}^{3}\right.$ year $\left.^{-1}\right)$} & & \multicolumn{3}{|c|}{$\mathbf{N}-\mathbf{T N}$ (Tn month-1) } & & \multicolumn{4}{|c|}{$\mathbf{P}-\mathbf{T P}($ Tn month-1) } \\
\hline & $91-95$ & 01- 05 & & & 91-95 & 01- 05 & & & $91-95$ & 01- 05 & & \\
\hline Seine Bay & 19121 & 22082 & n.s. & & 9433 & 12078 & $* *$ & $\uparrow$ & 995 & 455 & $* * *$ & $\downarrow$ \\
\hline Scheldt & 4636 & 4312 & n.s. & & 2851 & 2290 & n.s. & & 279 & 150 & $* * *$ & $\downarrow$ \\
\hline Somme & 1171 & 1398 & n.s. & & 437 & 493 & n.s. & & 17 & 13 & n.s. & \\
\hline Seine & 16826 & 19498 & n.s. & & 8489 & 10807 & $* *$ & $\uparrow$ & 915 & 417 & $* * *$ & $\downarrow$ \\
\hline Orne & 759 & 1100 & n.s. & & 530 & 628 & $*$ & $\uparrow$ & 14 & 10 & n.s. & \\
\hline Aulne & 793 & 664 & n.s. & & 576 & 385 & n.s. & & 9 & 6 & * & $\downarrow$ \\
\hline Blavet & 793 & 849 & n.s. & & 851 & 601 & n.s. & & 15 & 9 & $* *$ & $\downarrow$ \\
\hline Vilaine & 2354 & 1752 & n.s. & & 1635 & 1306 & n.s. & & 60 & 29 & $* * *$ & $\downarrow$ \\
\hline Loire & 29019 & 27232 & n.s. & & 9685 & 11903 & n.s. & & 1138 & 803 & n.s. & \\
\hline Dordogne & 9270 & 7451 & n.s. & & - & 1445 & - & & & 28 & - & \\
\hline Garonne & 20231 & 15926 & n.s. & & 5792 & 2915 & $* * *$ & $\downarrow$ & 224 & 142 & $* *$ & $\downarrow$ \\
\hline Adour & 10358 & 9035 & n.s. & & 2317 & 1588 & n.s. & & 114 & 91 & n.s. & \\
\hline Douro & 11045 & 18847 & n.s. & & 1266 & 2784 & $* *$ & $\uparrow$ & 73 & 155 & $* *$ & $\uparrow$ \\
\hline Tagus & 8424 & - & - & & 715 & 2218 & n.s. & & 280 & 198 & n.s. & \\
\hline Segura & 7 & 4 & n.s. & & - & 2 & - & & - & 0 & - & \\
\hline Jucar & 850 & 449 & * & $\downarrow$ & 174 & 48 & * & $\downarrow$ & 12 & 1 & $* * *$ & $\downarrow$ \\
\hline Ebro & 8364 & 9613 & n.s. & & 2384 & 2408 & n.s. & & 149 & 70 & $* * *$ & $\downarrow$ \\
\hline Aude & 1246 & 1075 & n.s. & & 247 & 213 & $*$ & $\downarrow$ & 33 & 10 & ** & $\downarrow$ \\
\hline Orb & 788 & 696 & n.s. & & 111 & 113 & n.s. & & 52 & 5 & $* * *$ & $\downarrow$ \\
\hline Herault & 1164 & 941 & n.s. & & 101 & 68 & n.s. & & 40 & 4 & $* * *$ & $\downarrow$ \\
\hline Vidourle & 243 & 288 & n.s. & & 40 & 29 & n.s. & & 1 & 1 & n.s. & \\
\hline Rhone & 57013 & 49953 & n.s. & & 11262 & 9947 & n.s. & & 559 & 438 & $* * *$ & $\downarrow$ \\
\hline Touloubre & - & 91 & - & & - & 26 & - & & - & 2 & - & \\
\hline Gapeau & 88 & 78 & n.s. & & - & 24 & - & & 2 & 2 & n.s. & \\
\hline Argens & 382 & 399 & n.s. & & 45 & 46 & n.s. & & 6 & 3 & $* * *$ & $\downarrow$ \\
\hline Arno & 2675 & 2671 & n.s. & & - & 994 & - & & - & 41 & - & \\
\hline Tiber & - & 5256 & - & & - & 2357 & - & & - & 121 & - & \\
\hline Po & 52348 & 44495 & n.s. & & - & 9473 & - & & - & 642 & - & \\
\hline Adige & - & - & - & & - & - & - & & - & - & - & \\
\hline
\end{tabular}



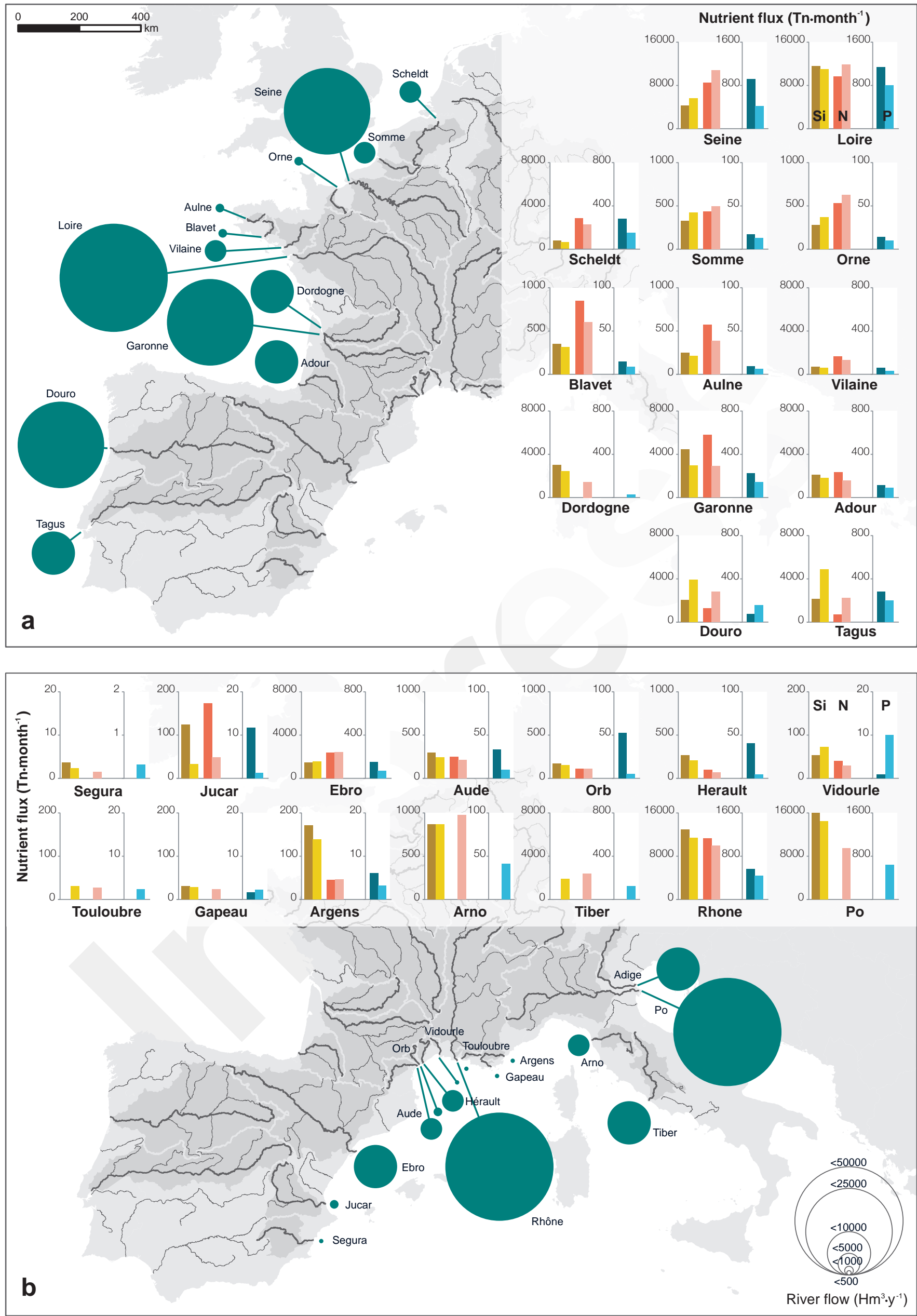

Fig. 1 Map of Europe showing average river flows (Hm3.y-1) in (a) the Atlantic and (b) the Mediterranean and the northern Adriatic coastal fronts. Inset bar charts show the corresponding average 5-year nutrient loads ( Tn/month). Silica (yellow bars) and nitrogen (N-TN, orange bars) are displayed on the same y-axis; phosphorus (P-TP, blue bars) has a different scale. Dark-shaded bars indicate nutrient fluxes between 1991 and 1995 and pale bars represent nutrient fluxes between 2001 and 2005 
2005 period. Ludwig et al. (2010) provide data on annual and 5-year P fluxes since the 1970 for a few Mediterranean rivers, including the Po, which can be directly compared to our results. According to these authors, there has been a remarkable decrease of $\mathrm{P}$ in the Rhone and the Ebro rivers after the 1990s, as we also observe, while minor changes occurred in the Po during the same period, mostly because large P reductions had already taken place some years before, notably after 1985.

In absolute terms, the highest P-ICEP values are currently observed in the Vidourle River (over 12 $\left.\mathrm{kg} \mathrm{C} \cdot \mathrm{km}^{2} \cdot \mathrm{d}^{-1}\right)$ and in the Scheldt River $\left(7 \mathrm{~kg} \mathrm{C} \cdot \mathrm{km}^{2} \cdot \mathrm{d}^{-1}\right)$, but there are some interesting differences between the two streams: the Vidourle is smaller (average flow, $288 \mathrm{Hm}^{3} \cdot \mathrm{y}^{-1}$ for the 2001-2005 period) and shows particularly high $P$ concentrations in the summer, which suggests a domestic origin; the flow of the Scheldt is 15 times greater (about $4312 \mathrm{Hm}^{3} \cdot \mathrm{y}^{-1}$ for the 2001-2005 period) and the highest $\mathrm{P}$ concentrations are recorded in the winter time. High winter values hint at the existence of a large diffuse source of $\mathrm{P}$, likely exported from soils treated with animal manure. Differences in the timing and the magnitude of the flow are important factors to be considered because they involve differences in the extent of the area potentially affected and point out the most sensitive periods of the year.

Further, seasonal variations of the P-ICEP are not uniform across coastal fronts (Fig. 2b, c). In the Mediterranean, some rivers show higher index values in the summer (the Ebro, Rhone, Gapeau, Argens and Arno), but in others the maximum P excess occurs during the winter (Herault, Orb, Touloubre and Tiber). In the Atlantic, P-ICEP summer values are consistently higher than winter ones. In fact, the reduction of $\mathrm{P}$ inputs during the past decade has had a particularly relevant effect on winter P-ICEPs because the index computes, by definition, the relative excess of $\mathrm{P}$ with regard to $\mathrm{Si}$, and $\mathrm{Si}$ inputs tend to be greater in the winter when the river flow is more abundant. Nevertheless, whether the indicator is maximum in summer or winter is also related to the type of source and will be fully discussed below.

Nitrogen inputs. N fluxes have remained steady or decreased with regard to the 1990s in the Mediterranean (-19\% on average) and in several Atlantic streams, but some increases are found in large rivers such as the Loire, the Douro and the Tagus. The two Portuguese rivers show the highest decadal variations, with increases of over $120-200 \%$. Note, however, that differences between time periods are not statistically significant for the Loire and the Tagus owing to high intra-annual variability. It is also remarkable that the Orne, the Seine and the Somme, all three flowing into the English Channel and confined within a small geographical area, have increased their $\mathrm{N}$ fluxes by approximately $20 \%$ since the 1990s. According to the 5-year average fluxes in Ludwig et al. (2010), N inputs have remained steady in the Po after the 1990s. 


\section{Fig. 2a}
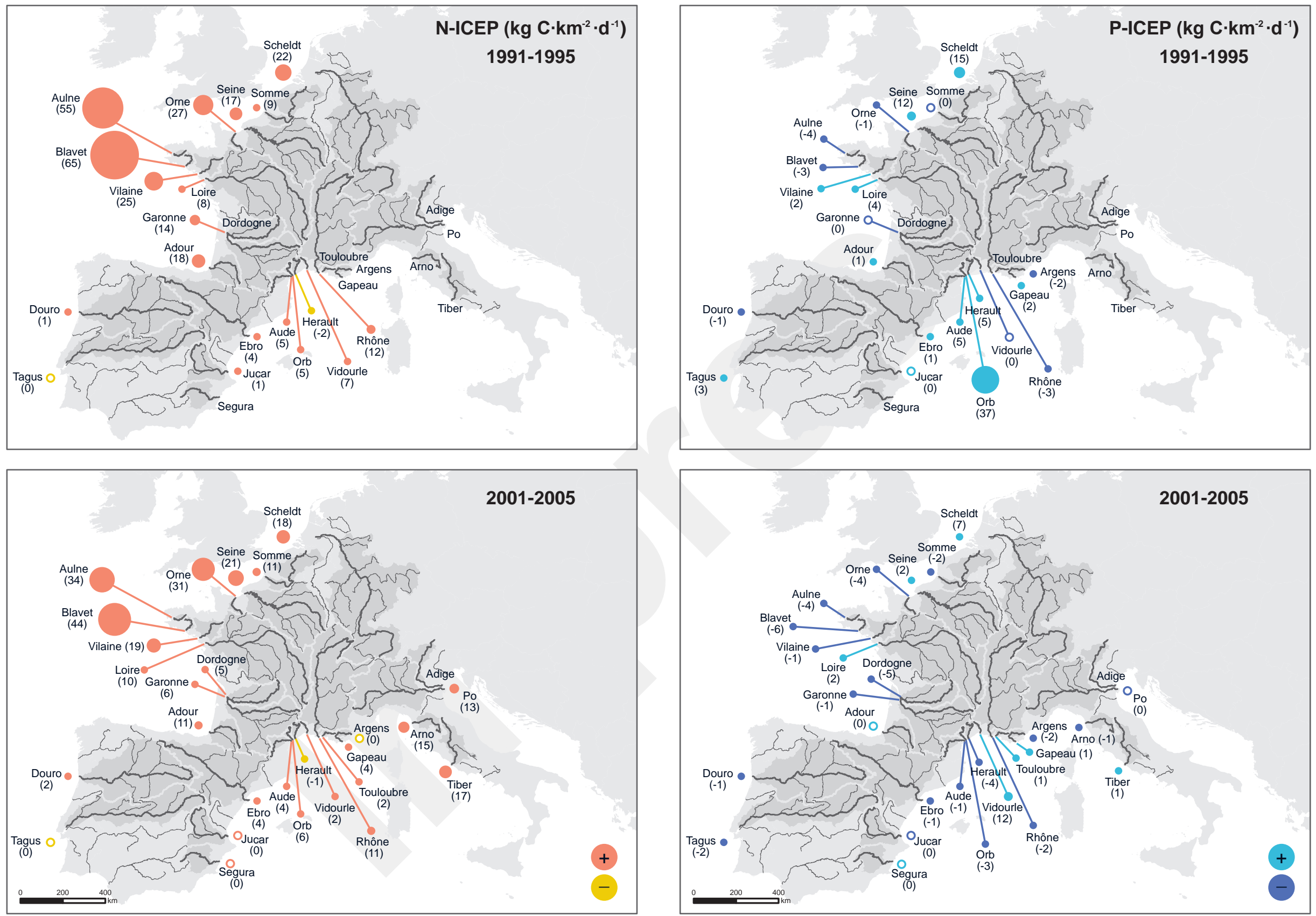

Fig. 2 N-ICEP and P-ICEP for several rivers in southwestern Europe. (a) Average value for the 1991- 1995 and 2001-2005 periods; (b) average summer and (c) winter values during the same 5-year periods. For N-ICEPs, orange symbols represent positive values and yellow circles represent negative values; for P-ICEPs, light blue indicates positive values and dark blue negative values 
Fig. 2b
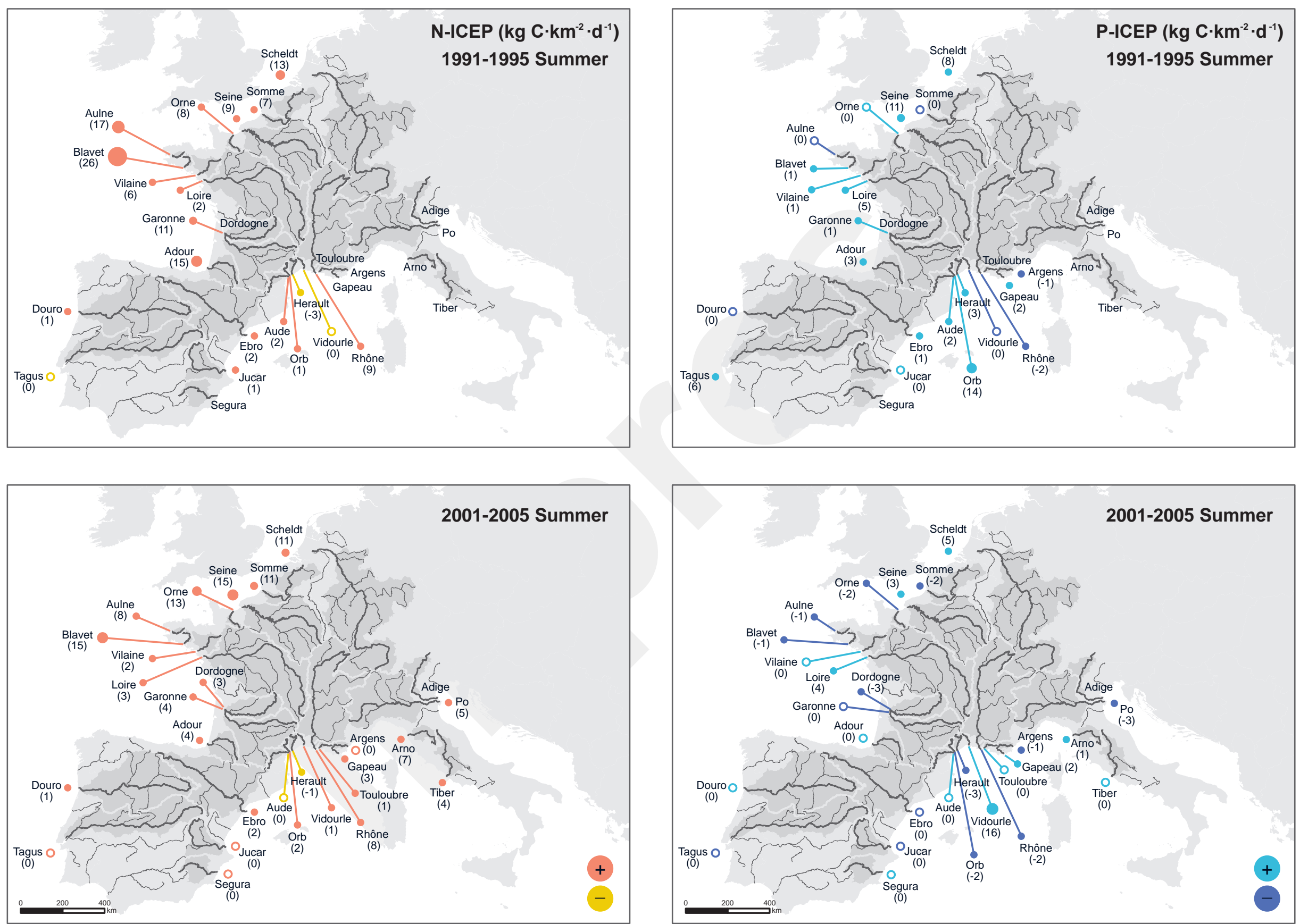
Fig. 2c
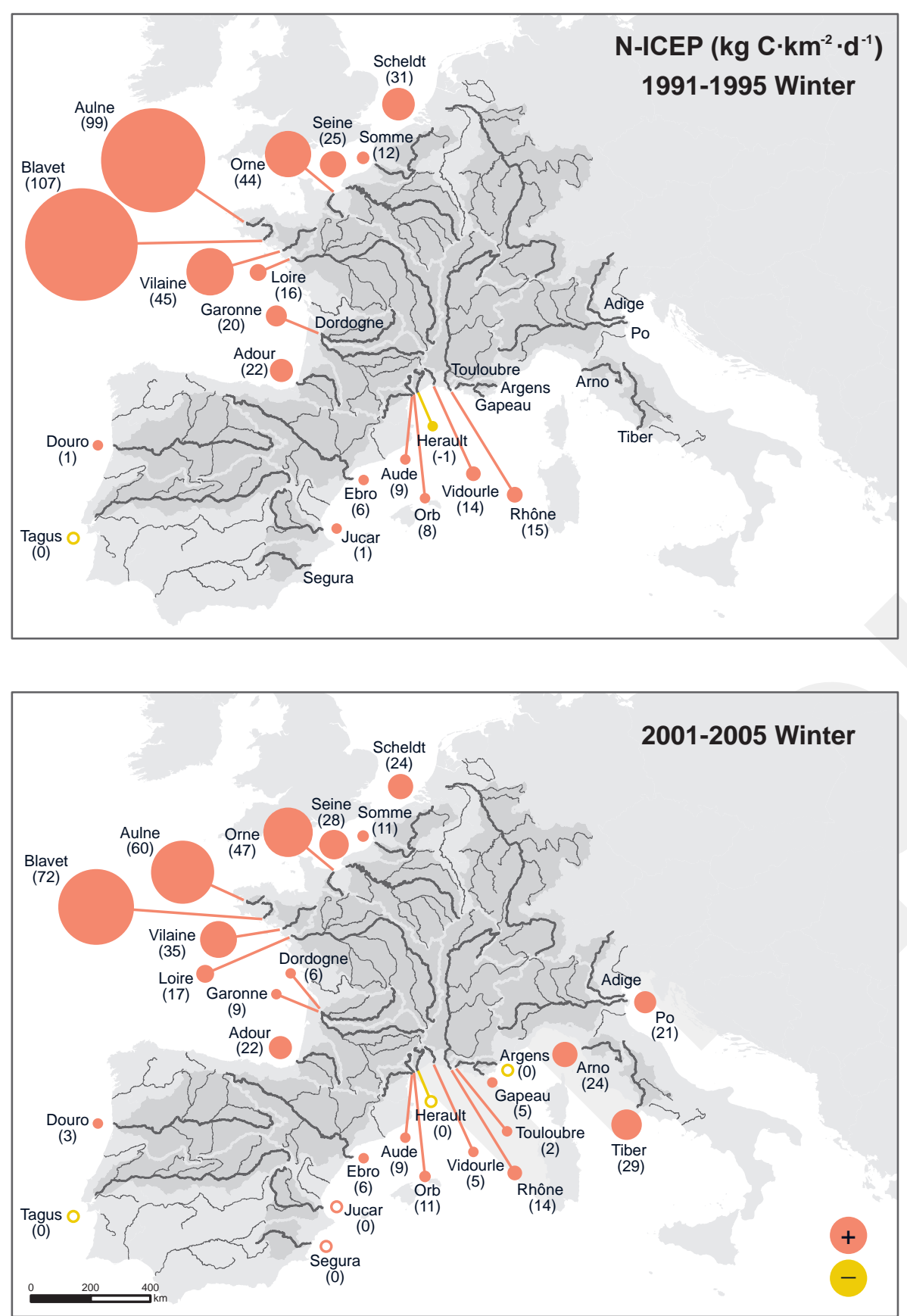
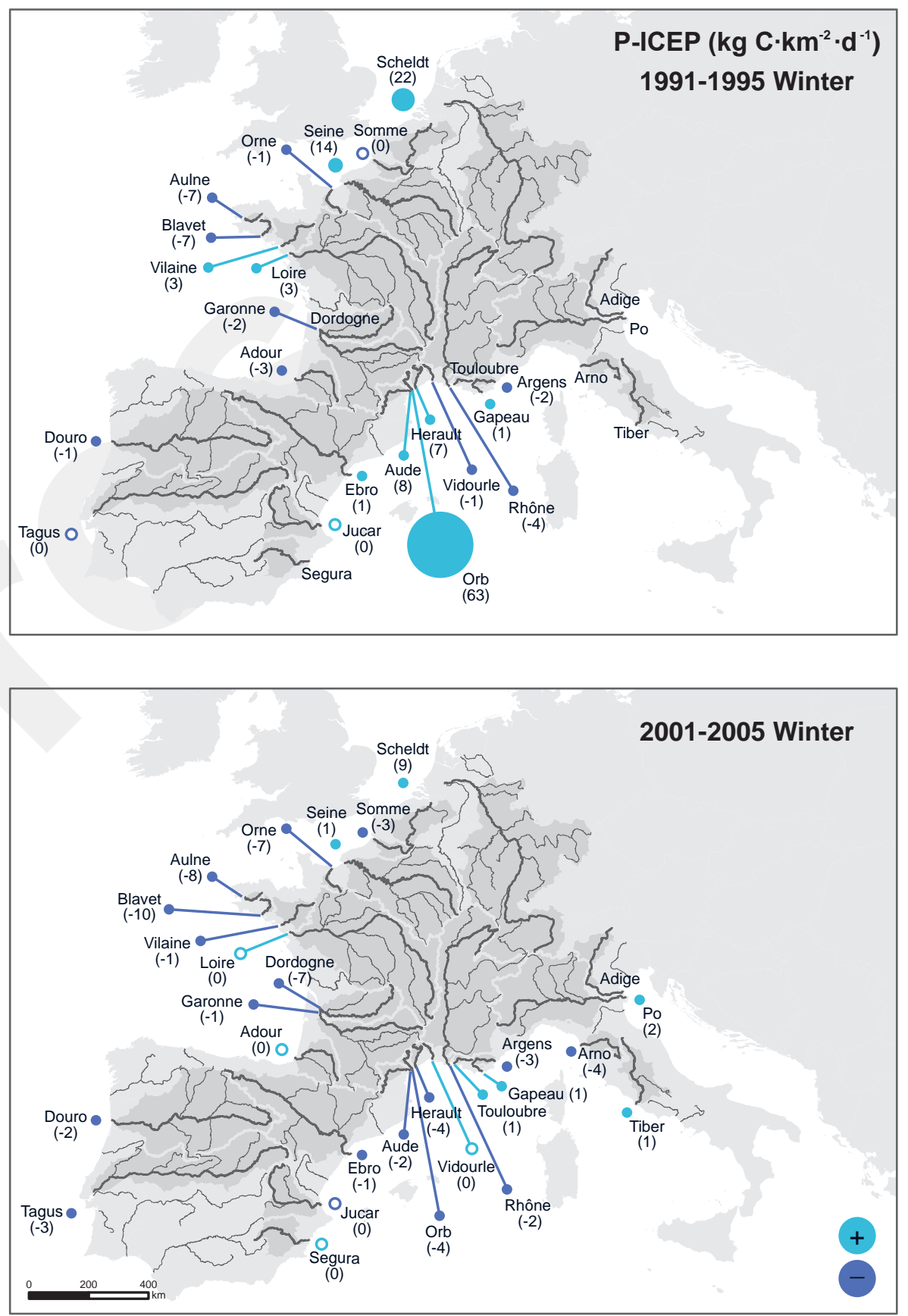
Regardless of the increasing or decreasing decadal trends, the N-ICEP index is positive in almost all cases, indicating a clear and widespread $\mathrm{N}$ excess with respect to silicate (Fig. 2a). In the Mediterranean, the highest N-ICEP values are observed along the Italian coast (Arno and Tiber rivers). The largest absolute values are found in Brittany and along the eastern English Channel, where the index reaches about $40 \mathrm{~kg} \mathrm{C} \cdot \mathrm{km}^{2} \cdot \mathrm{d}^{-1}$.

With regard to seasonal variations, N-ICEP values are systematically higher in winter (Fig. 2b, c). The seasonal asymmetry is very clear in the Atlantic rivers, but it is somewhat smoothed in the Mediterranean. This is consistent with the fact that $\mathrm{N}$ sources are mostly of a diffuse origin and thus directly linked to the corresponding flow regime.

\subsubsection{Time series data and average standard year}

The analysis of the time series is useful to pinpoint those rivers where there have been drastic shifts in the concentration of nutrients or where the dynamics of $\mathrm{N}$ and $\mathrm{P}$ has clearly diverged, and so to determine the points of inflexion, also in the light of changes in human activities within the watersheds. In the Mediterranean, there was a rapid decrease of $\mathrm{P}$ inputs in the Rhone, the Ebro, the Jucar, the Orb and the Herault rivers after the mid-1990s (Table 4). Similar abatements have occurred on the Atlantic coast (the Garonne, Blavet, Vilaine, Seine) since the beginning of the 2000s. At the Somme River, positive P-ICEP values were continuously observed before 1995 but shifted to negative values after 1999. N-ICEP changes, either increases or decreases, have been much more progressive in time. Additionally, the time series allows us to see to what extent annual and seasonal average values correspond to regular cycles, steady monthly values, or are the result of spiky, fluctuating dynamics. In this regard, Mediterranean rivers tend to have large, uneven variations over the years studied, with alternate periods of positive and negative ICEP values, while more regular cycles are found in the Atlantic (e.g., the Loire, Vilaine, Blavet and Seine), particularly for N inputs. Part of this variability is linked to the characteristic hydrological regime of Mediterranean versus pluvial oceanic streams, as previously observed with seasonal features.

To better illustrate the differences between coastal fronts, we selected four characteristic rivers (the Seine, the Loire, the Ebro and the Rhone) and we analyzed their time series in greater detail (Fig. 3). Further, using all data available for each river we calculated an average year to identify the dominant intra-annual variations and to determine whether there are particularly susceptible periods of the year when the excess of $\mathrm{N}$ or $\mathrm{P}$ with regard to $\mathrm{Si}$ reaches maximal values.

In the Seine and the Loire, we can clearly distinguish two opposite trends: P-ICEP values have largely decreased over the years, notably by the end of the 1990s, but concomitant N-ICEP values have 


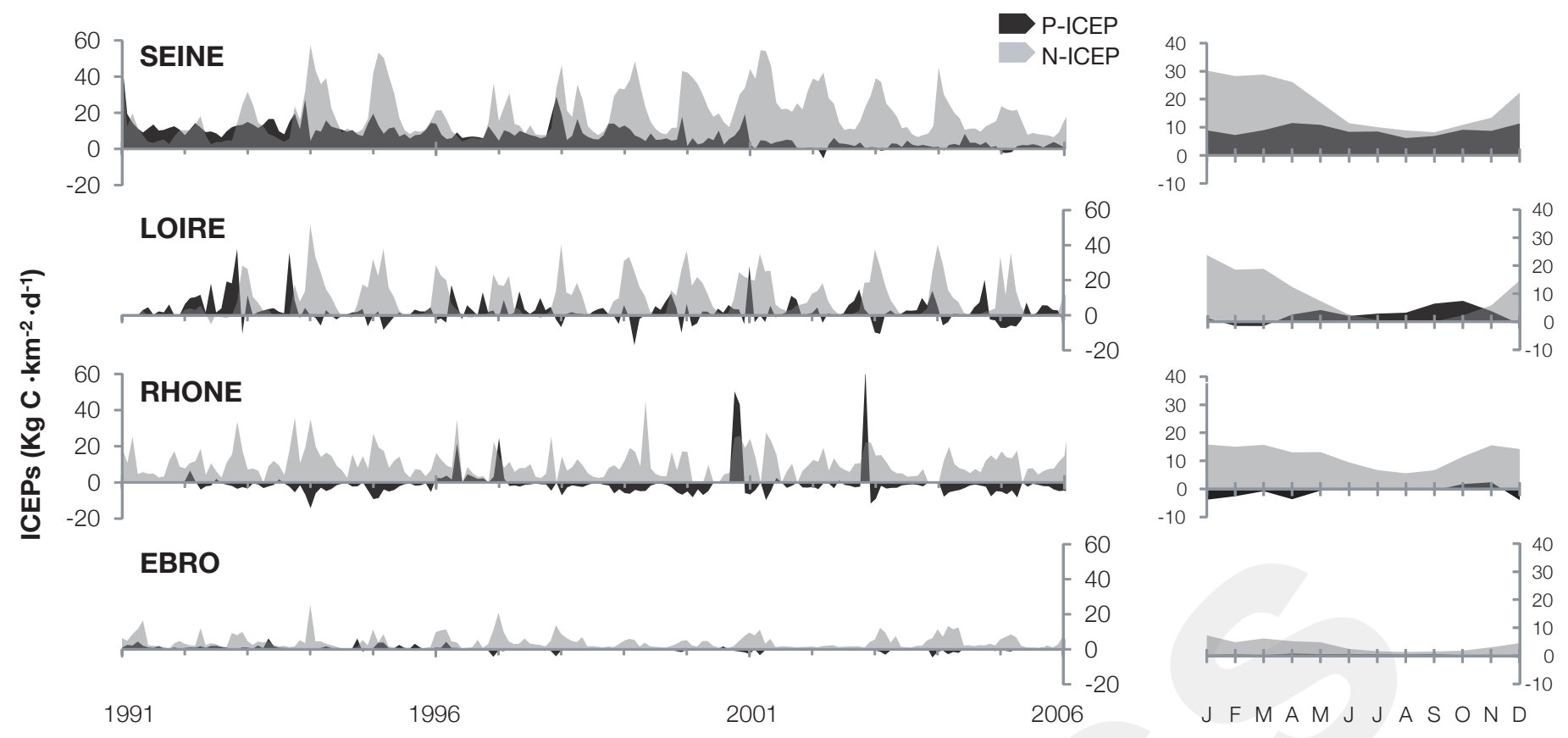

Fig. 3 N-ICEP and P-ICEP time series and average standard year for the Seine, Loire, Rhone and Ebro rivers 
increased (Table 5). In the Seine, with the exception of a few short periods, positive values for both Nand P-ICEP are always found, meaning that the risk of eutrophication remains high. In the Loire, negative P-ICEP values occur in the winter, at the times when N-ICEP is highly positive, whereas positive P-ICEPs are regularly observed in summer and autumn; the limited overlap between positive periods of both indicators suggests alternate nutrient limitations and restricts the periods of potentially high eutrophication risk. In the Rhone and the Ebro, the $\mathrm{P}$ excess has decreased and $\mathrm{N}$ has remained steady or slightly decreased over time; P-ICEP is consistently negative in both rivers (except for some episodic winter peaks in the Rhone), which may indicate that phosphorus exerts some control on the eutrophication risk. The eutrophication potential is, in any case, moderate to low with regard to the Atlantic rivers.

The plots on the right in Fig. 3 show the dynamics of both indicators during an average year. Note that, regardless of the difference in magnitude, N-ICEP in all four rivers is clearly related to river flow: it peaks from late autumn through winter and remains low in the summer. In general, the P indicator presents less systematic annual trends because phosphorus inputs are not so dependent on diffuse sources. Finally, while $\mathrm{N}$ is largely in excess throughout the year in the Seine, the Rhone and the Ebro, the Loire features large $\mathrm{N}$ pools in the winter but a progressive change toward $\mathrm{P}$ excess during the summer period, a pattern that is repeated in other Atlantic streams (e.g., the Vilaine, Blavet and Aulne).

In summary, our data show general P decreases in most catchments over southwestern Europe, while minor, if any, simultaneous $\mathrm{N}$ reductions. This is in accordance with previous studies that had detected decreasing $\mathrm{P}$ trends in individual catchments (Garnier et al. 2010; Ibáñez et al. 2008; Lefebvre et al. 2011) and with recent modeling results (Grizzetti et al. 2012), and has eventually led to an exacerbated $\mathrm{N}$ imbalance in many river systems.

\subsection{Phytoplankton biomass}

\subsubsection{Freshwater chlorophyll}

Although when talking about eutrophication effects of river inputs we normally refer to the related problems in coastal areas, nutrient overload also promotes the growth of phytoplankton in freshwaters. Changes in riverine chlorophyll should naturally track changes in nutrient concentrations and ultimately provide supporting evidence on long-term shifts. Time series of freshwater chlorophyll were obtained for all rivers in the study except for the rivers in Spain and Italy, where only data on nutrient concentration were available. To allow direct comparisons with nutrient fluxes, we split the data into 5-year periods and plotted the results on matching European maps (Fig. 4). There is a 
Table 5. Summary of statistical results from the trend analysis (Seasonal Kendall test). Bold values are significant at $\mathrm{p}<0.1$. Arrows on the right indicate the increasing or decreasing trend.

\begin{tabular}{|c|c|c|c|c|c|c|c|c|}
\hline \multirow[b]{3}{*}{ Seine Bay } & \multicolumn{4}{|c|}{ ICEP-N } & \multicolumn{4}{|c|}{ ICEP-P } \\
\hline & \multirow{2}{*}{$\begin{array}{r}\text { All year } \\
1.275\end{array}$} & \multirow{2}{*}{$\begin{array}{r}S \\
1.296\end{array}$} & \multicolumn{2}{|l|}{ W } & \multirow{2}{*}{$\begin{array}{r}\text { All year } \\
1.200\end{array}$} & \multirow{2}{*}{$\frac{S}{1.200}$} & \multicolumn{2}{|l|}{$\mathrm{W}$} \\
\hline & & & 1.286 & $\uparrow$ & & & 1.200 & $\downarrow$ \\
\hline Scheldt & 1.284 & 1.257 & 1.228 & & 1.209 & 1.250 & 1.202 & $\downarrow$ \\
\hline Somme & 1.259 & 1.246 & 1.217 & & 1.200 & 1.200 & 1.200 & $\downarrow$ \\
\hline Seine & 1.271 & 1.268 & 1.207 & $\uparrow$ & 1.200 & 1.200 & 1.200 & $\downarrow$ \\
\hline Orne & 1.201 & 1.200 & 1.202 & $\uparrow$ & 1.200 & 1.200 & 1.200 & $\downarrow$ \\
\hline Aulne & 1.275 & 1.294 & 1.208 & & 1.200 & 1.211 & 1.200 & $\downarrow$ \\
\hline Blavet & 1.277 & 1.208 & 1.223 & & 1.200 & 1.202 & 1.214 & $\downarrow$ \\
\hline Vilaine & 1.226 & 1.266 & 1.204 & $\uparrow$ & 1.226 & 1.204 & 1.237 & $\downarrow$ \\
\hline Loire & 1.212 & 1.227 & 1.205 & $\uparrow$ & 1.210 & 1.233 & 1.202 & $\downarrow$ \\
\hline Dordogne & 1.225 & 1.290 & 1.270 & $\downarrow$ & 1.252 & 1.229 & 1.243 & \\
\hline Garonne & 1.254 & 1.253 & 1.234 & $\downarrow$ & 1.206 & 1.203 & 1.246 & $\downarrow$ \\
\hline Adour & 1.263 & 1.203 & 1.298 & $\downarrow$ & 1.238 & 1.240 & 1.277 & \\
\hline Douro & 1.291 & 1.253 & 1.280 & $\uparrow$ & 1.258 & 1.249 & 1.244 & $\downarrow$ \\
\hline Tagus & 1.280 & 1.222 & 1.216 & & 1.205 & 1.288 & 1.243 & \\
\hline Segura & 1.283 & - & 1.222 & & 1.241 & - & 1.271 & \\
\hline Jucar & 1.284 & 1.293 & 1.282 & & 1.201 & 1.201 & 1.203 & $\downarrow$ \\
\hline Ebro & 1.290 & 1.252 & 1.255 & & 1.200 & 1.200 & 1.200 & $\downarrow$ \\
\hline Aude & 1.260 & 1.253 & 1.206 & & 1.205 & 1.217 & 1.201 & $\downarrow$ \\
\hline Orb & 1.243 & 1.259 & 1.229 & & 1.200 & 1.200 & 1.200 & $\downarrow$ \\
\hline Herault & 1.297 & 1.254 & 1.244 & $\uparrow$ & 1.201 & 1.208 & 1.203 & $\downarrow$ \\
\hline Vidourle & 1.262 & 1.267 & 1.250 & $\downarrow$ & 1.231 & 1.242 & 1.243 & $\downarrow$ \\
\hline Rhone & 1.208 & 1.229 & 1.235 & & 1.200 & 1.200 & 1.200 & $\downarrow$ \\
\hline Touloubre & 1.236 & 1.280 & 1.293 & & 1.201 & 1.202 & 1.202 & $\downarrow$ \\
\hline Gapeau & 1.250 & 1.237 & 1.293 & & 1.217 & 1.223 & 1.253 & \\
\hline Argens & 1.202 & 1.287 & 1.202 & $\uparrow$ & 1.286 & 1.213 & 1.231 & $\downarrow$ \\
\hline Arno & 1.210 & 1.272 & 1.264 & & 1.289 & 1.214 & 1.238 & $\uparrow$ \\
\hline Tiber & 1.221 & 1.202 & 1.217 & & 1.217 & 1.202 & 1.202 & \\
\hline Po & 1.279 & 1.248 & 1.251 & & 1.257 & 1.273 & 1.288 & \\
\hline Adige & 1.296 & - & 1.217 & & 1.296 & - & 1.202 & \\
\hline
\end{tabular}



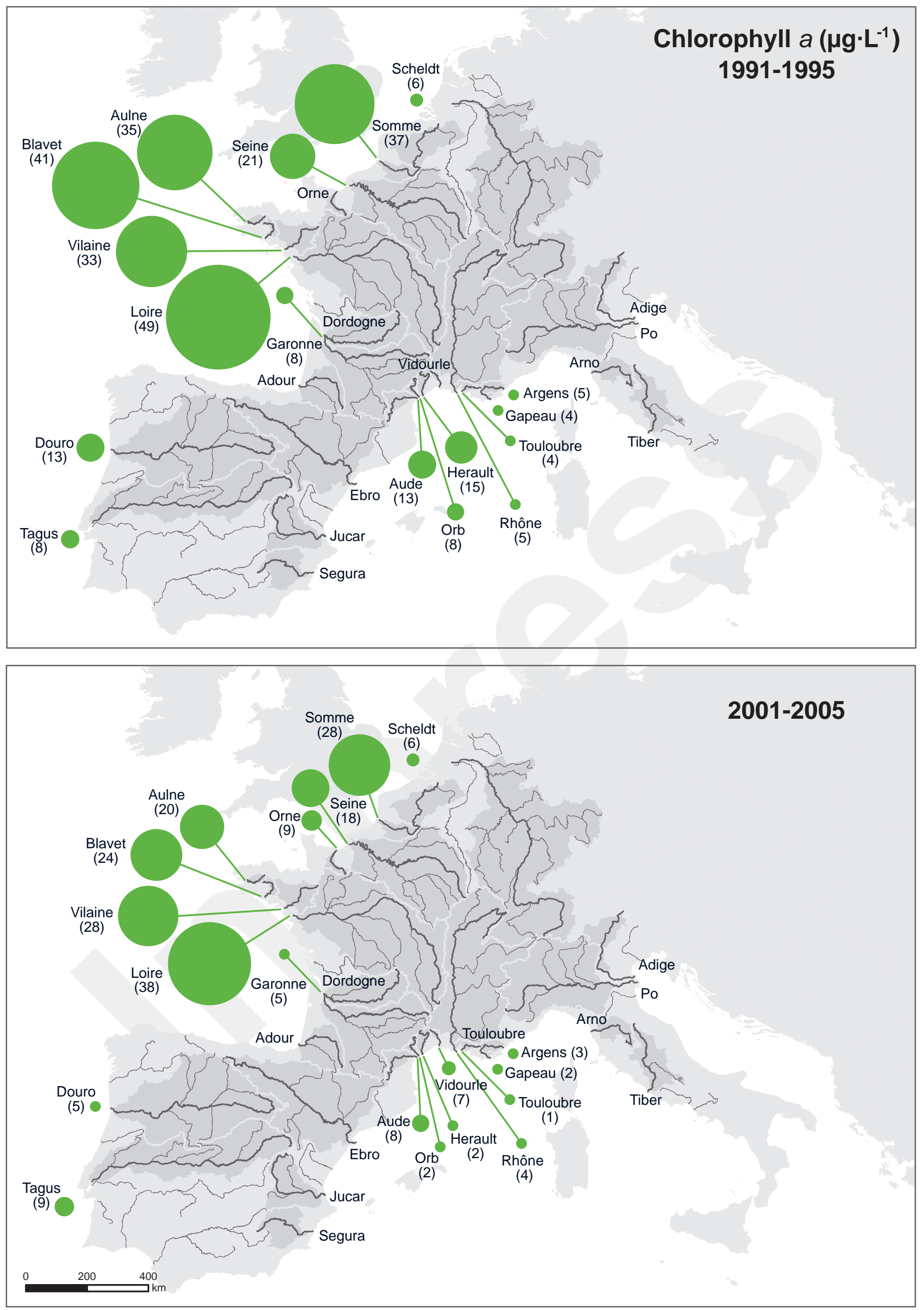

Fig. 4 Concentration of freshwater chlorophyll $(\mu \mathrm{g} \cdot \mathrm{L}-1)$ in several European rivers for the 1991-1995 and 2001-2005 periods 
widespread decrease of freshwater chlorophyll in all coastal fronts examined, with an average drop between the two periods of $-54 \%$ for the Mediterranean and $-26 \%$ in the Atlantic and the eastern English Channel (both of them statistically significant, $\mathrm{p}<0.05$ ). Interestingly, these two values coincide with average $\mathrm{P}$ reductions in their respective coastal fronts (-53\% in the Mediterranean, $-24 \%$ in the Atlantic and the English Channel).

\subsubsection{Coastal chlorophyll: the Seine Bay case-study}

Although the Seine accounts for up to $80-85 \%$ of the freshwater inflow in the area, eight other rivers were considered to calculate $\mathrm{N}$ and $\mathrm{P}$ fluxes, covering the whole bay (namely, the Touques, Dives, Orne, Seulles, Aure, Vire, Taute, and Douve). Consistent with the trends observed so far for the eastern English Channel, the $\mathrm{N}$ load in the area remains high, while there has been a remarkable decrease of P. In accordance, the N-ICEP index has slightly increased and stabilized while the P-ICEP has dropped and currently presents very low or negative values (Fig. 5).

We analyzed the chlorophyll series for different stations in the bay (17 in total); the coastal monitoring program, RHLN, started in 2000 and so data exist only for the 2000-2010 period. Given the multiplicity of forcing factors operating at each particular site, and provided that we search for extensive, generalized effects, we calculated the average chlorophyll concentration for the whole bay. As such, we smoothed out the local variability and obtained an integrative variable that could be directly compared with river inputs. When the Seasonal Kendall test was performed to search for temporal patterns, two trends emerged ( $p<0.01$ in both cases): there has been a significant decrease of summer chlorophyll during the last 10 years, but simultaneously a mild increase of winter chlorophyll concentrations (Fig. 5).

We used the data on phytoplankton composition from the REPHY network to explore whether the changes in chlorophyll concentration were particularly due to certain phytoplankton species and whether we could single out groups of organisms that are especially favored or impaired when nutrient loads in the bay are high. We focused on two large functional groups - diatoms and dinoflagellates because these are dominant in the Seine Bay (Belin et al. 1995; Videau et al. 1998). Again, we integrated the results of several stations to obtain an average figure for the entire bay. For dinoflagellates, we observe a general decrease in average and maximum monthly concentrations (Fig. 6), but by splitting the data into summer and winter periods, a significant increase of summer abundances can be seen (SK test, $\mathrm{p}<0.05$ ). If we further look at target species that cause problems of harmful blooms and toxicity (e.g., Dinophysis spp.), no clear correspondence is apparent between the number of toxic episodes and the decrease in average cell numbers, nor with the magnitude of the annual peak (Fig. 6). For diatoms, both average monthly concentrations and maximum abundances 

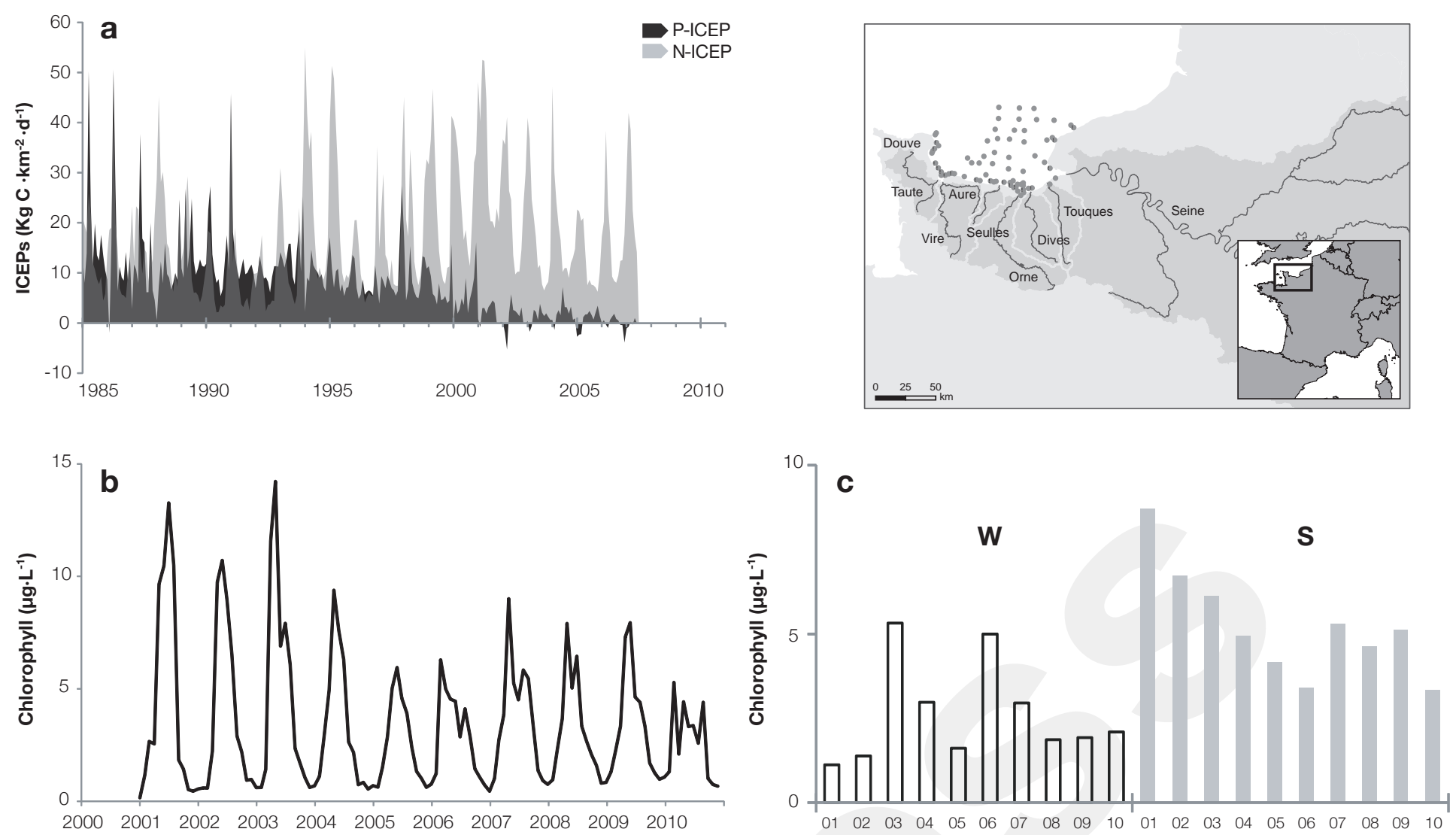

Fig. 5 (a) N-ICEP and P-ICEP in the Seine Bay; (b) time series of chlorophyll concentration (integrated value for the whole bay) and (c) separated summer and winter chlorophyll values. The map on top shows the nine rivers considered to calculate the ICEPs and the 17 RHLN stations included to compute the average chlorophyll concentration in the bay 
show nonsignificant variations. The potentially toxic Pseudo-Nitzschia spp. show a recent decrease in maximum numbers and blooming episodes, yet again years of high Pseudo-Nitzschia spp. concentrations do not necessarily coincide with years with a large number of toxic episodes.

\section{DISCUSSION}

\subsection{Temporal patterns: the importance of seasonal features}

One of the things that we were most interested in within the present study was the variability of river inputs throughout the year. Most large-scale studies addressing river inputs provide annual estimates of nutrient fluxes but do not give information on seasonal patterns. Notwithstanding, seasonality is of the highest importance when dealing with eutrophication issues because phytoplankton growth is naturally constrained by factors that follow seasonal cycles.

Phosphorus comes mainly from industrial and domestic waste waters, so that inputs do not follow a seasonal pattern but are rather homogeneous throughout the year. In the winter, the river flow and the silica content are naturally high; inputs of $\mathrm{P}$ from point sources are therefore diluted and there is a relative shortage of $\mathrm{P}$ with regard to silica, i.e., negative $\mathrm{P}$-ICEP values. In the summer, point sources contribute largely to the total freshwater flow and $\mathrm{P}$ can easily become an excess nutrient. The reduction of $\mathrm{P}$ is hence particularly effective in the summer, when the risk of eutrophication due to $\mathrm{P}$ overload is higher. On the contrary, $\mathrm{N}$ inputs come mostly from diffuse sources and further increases occur chiefly in the winter, at the time of high water fluxes. $\mathrm{N}$ can thus accumulate during the cold period and accumulate into a high stock at the beginning of spring, enhancing phytoplankton growth at the coastal zone during the spring bloom.

More precisely, the large $\mathrm{N}$ and $\mathrm{Si}$ supply during the winter, together with $\mathrm{P}$, promotes the early growth of diatoms in spring, which consume only part of the available $\mathrm{N}$ and $\mathrm{P}$ but can deplete $\mathrm{Si}$ stocks. The excess pool of $\mathrm{N}$ and $\mathrm{P}$ can then be consumed by non-siliceous algae, as occurs in the North Sea with Phaeocystis spp., a flagellate that appears at the beginning of spring and is responsible for numerous episodes of foam formation (Lancelot 1995; Lancelot et al. 2005; Lefebvre et al. 2011). The larger the nutrient leftover, the larger the potential bloom. Subsequent summer freshwater inputs are enriched in $\mathrm{P}$ (and $\mathrm{N}$ ) but contain relatively less $\mathrm{Si}$. Again, the Si deficiency can exacerbate the dominance of non-siliceous organisms in late summer and particularly favor several groups of flagellates and dinoflagellates (Guillaud \& Ménesguen 1998).

The development of dinoflagellates is indeed consistent with our results in the Seine Bay, where these organisms are the cause of periodic fishing bans (Amzil et al. 2007). The trend analysis showed 

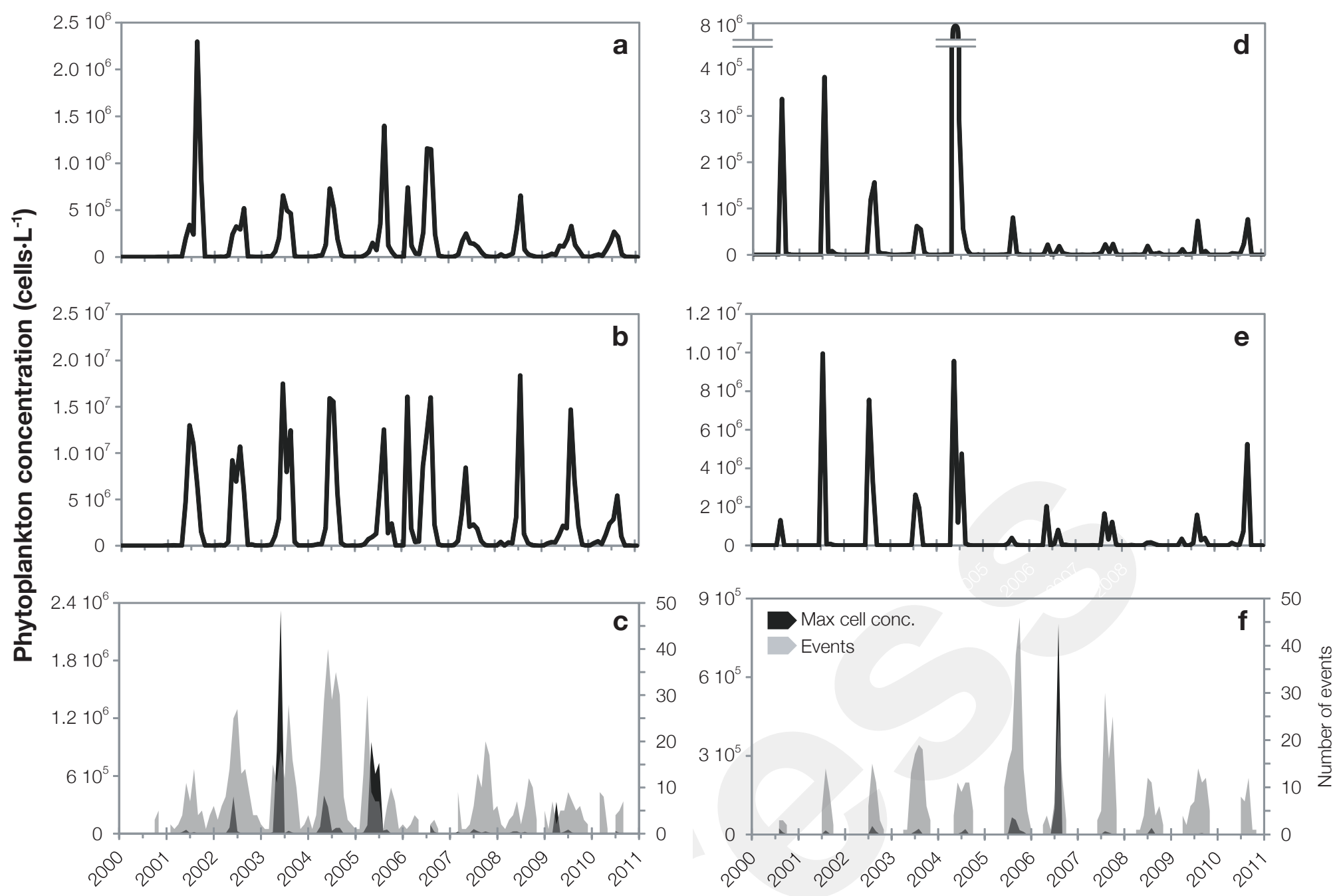

Fig. 6 Phytoplankton concentration (cells.L-1) in the Seine Bay. (a) Average and (b) maximum concentration of diatoms; (c) maximum cell abundance of the potentially toxic diatom Pseudo-Nitzschia spp. (dark grey) and number of samplings in which the species is present (light grey). (d) Average and (e) maximum concentration of dinoflagellates in the bay; (f) maximum concentration of the dinoflagellate Dinophysis spp. (dark grey) and number of samplings in which the species is present (light grey) 
an increase of chlorophyll and total phytoplankton cells in the winter, in parallel with the increase of $\mathrm{N}$ fluxes (SK test, $\mathrm{p}<0.05$ ), while a decrease of chlorophyll was observed in the summer, likely induced by the drop of $\mathrm{P}$ (SK test, $\mathrm{p}<0.01$ ). Surprisingly, no significant trends were found for diatom abundances, although the phytoplankton community in the Seine Bay (notably the annual spring bloom) is largely dominated by diatom species (Videau et al. 1998; Cugier et al. 2005). This may be due to great intra-annual variability and the fact that we have averaged several months for a group of stations. When performing the SK test and separating by month, significant diatom increases appeared in February, March and April (SK test, p < 0.1). Even more interesting, dinoflagellates showed a significant increase in the summer. This stresses that phosphorus reductions can help reduce total phytoplankton biomass but are not sufficient to control harmful blooms. Phosphate is known to be a labile compound rapidly consumed and recycled by planktonic organisms so that, provided there is available $\mathrm{N}$, blooms can develop even in the presence of apparently low $\mathrm{P}$ concentrations. The increasing nutrient imbalance may further benefit specific organisms and deeply alter the marine trophic network (e.g., Thingstad \& Billen 1994; Schoemann et al. 2005; Glibert et al. 2010).

Although it is clear that a relationship exists between algal biomass and the $\mathrm{N}$ and $\mathrm{P}$ load of coastal waters, it is not possible to conclude the extent to which shifts in HABs can be attributed to the increase or decrease in riverine nutrient levels because other factors may be involved. Thus, hydraulic flushing, stratification, salinity and sediment loading, all related to freshwater inflows, can act upon the initiation or ending of noxious blooms by various mechanisms, and they have been shown to affect a wide range of taxa, including cyanobacteria, dinoflagellates, diatoms and prymnesiophytes (see Roelke \& Pierce 2011 and references therein). Further, the importance of organic nutrient sources and alternate trophic pathways, such as mixotrophy, on eutrophication issues has been recently called to attention by some authors (e.g., Anderson et al. 2008; Kudela et al. 2008; Glibert et al. 2010). Little or no data at all are available to determine the influence of these factors on most coastal systems. Additional difficulties relating land-based nutrient inputs to phytoplankton changes are due to the biological sampling strategy. As pointed out by Ferreira et al. (2011), sampling is often designed to capture extreme or problematic events or time periods, and in places with strong seasonal variability, it can be limited to samples from the typical bloom period to try to capture peak concentrations, usually the spring or summertime growing season. This happens in some stations of the Seine Bay and hinders the detection of temporal trends, particularly with regard to singular toxic species. Ideally, samples should be taken year round to observe both baseline and bloom concentrations.

\subsection{Spatial patterns: Mediterranean versus Atlantic rivers}


Beyond the common seasonal trends described above, Atlantic and Mediterranean rivers present a series of specific characteristics that are worth considering. First, despite the existing surplus of $\mathrm{N}$ with regard to $\mathrm{Si}$ in both coastal fronts, the excess is particularly high in Atlantic rivers: on average, the NICEP is fourfold higher ( 20 vs. $\left.4.5 \mathrm{~kg} \mathrm{C} \cdot \mathrm{km}^{-2} \cdot \mathrm{d}^{-1}\right)$. This may be related to the fertilizer application rates, which were traditionally higher in northern than in southern European countries (Crouzet et al. 1999). The lower excess of nitrogen in Mediterranean streams, however, does not necessarily mean that catchments are less overloaded in $\mathrm{N}$ than those in other parts of Europe but instead can be concealed by different hydrological dynamics. Lassaletta et al. (2012) have shown that in the Ebro River, a typical Mediterranean catchment subject to episodic droughts, flow-regulated and highly channelized, the outflow of nitrogen to coastal waters is relatively low because most $\mathrm{N}$ compounds are retained within the catchment.

Second, dissimilar climatological factors, notably the pluviometric regime, form the basis for different intra-annual characteristics. In general, Atlantic streams present regular annual fluctuations, with a large winter flow peak and lower values in the summer. Accordingly, there is a large excess of $\mathrm{N}$ in the wintertime (positive N-ICEP values) that decreases toward the summer, when the P-ICEP is highest. This creates a regular interval of overlap during the warm period, at the time when the growth of phytoplankton is maximal. In Mediterranean rivers, freshwater discharge follows similar annual patterns, i.e., flow is maximum in the winter and lower in the summer, but cycles are less regular and their magnitude varies substantially from year to year. In addition, winter/ summer differences are smoothed in some rivers due to artificial flow regulation and there are many episodic flow peaks. Extreme flow peaks (flash floods) correspond, in most cases, to heavy downpours that occur in late summer-early autumn and winter (Estrela et al. 2001; Ludwig et al. 2003). As a result, the overlapping periods of $\mathrm{N}$ and $\mathrm{P}$ excess, i.e., the times of maximal potential eutrophication risk, are less systematic. Additionally, sediment loads in Mediterranean rivers are naturally high (Milliman et al. 2001; Ludwig et al. 2003) and this may partly prevent phytoplankton growth during flow peaks despite the accompanying nutrient inflows to coastal waters. These hydrological differences between Mediterranean and temperate catchments and their influence on coastal eutrophication are also interesting to consider in view of climate change. Under climate change scenarios, hydrometeorological models predict changes in the timing of flows (a shift from spring snow melt to winter runoff), a prolongation of the dry period and an increase of the extreme flows (high and low) across a large part of continental Europe (Arnell 1999; Mimikou et al. 1999). Such conditions would thus approach those found in Mediterranean regions.

Third, the appearance of eutrophic coastal waters is clearly related to nutrient inputs, but it is also strongly dependent on the physical characteristics of the receiving coastal zone (Rabouille et al. 2008). 
Tidal range and associated processes (e.g., tidal mixing, current velocity, light penetration and sediment resuspension) influence phytoplankton biomass in estuaries and can help alleviate the effects of nutrient overload by contributing to a regular exchange with offshore waters (Monbet 1992). This can be somewhat advantageous in the Atlantic littoral but not in the Mediterranean, where tidal range is on the order of tens of centimeters. Locally, enclosed bays and areas of confined waters are sensitive areas where excess nutrients can rapidly foster the emergence of algal blooms (Tett et al. 2003). The same occurs in bays sheltered by bar sands and in shallow harbors, because they favor the formation of cyst seedbeds and hinder the dispersion of the organisms (Vila et al. 2001). Local features can modulate the response of algae to nutrient inputs beyond larger-scale regional patterns and must be considered when addressing the eutrophication risk of specific coastal locations. Likewise, local characteristics may determine, to a large extent, the resilience of the system (e.g., Kemp et al. 2005).

\subsection{General considerations on $\mathbf{N}$ and $P$ fluxes}

Our study compiles information on 28 rivers subject to different environmental conditions, both in terms of socioeconomic factors and in relation to climate and physical characteristics (Metzger et al. 2010). This provides a broad spectrum that allows us to identify general trends and draw conclusions applicable to vast areas in SW Europe. As a whole, our data show that $\mathrm{N}$ has remained stable in most river systems, with only moderate increases or decreases from the 1990s until now. Moreover, even in those areas where the drop of $\mathrm{N}$ is significant, the excess $\mathrm{N}$ with regard to $\mathrm{Si}$ is remarkable and N-ICEP values remain positive. This is consistent with the large $\mathrm{N}$ enrichment currently observed in many European freshwater bodies (Grizzetti et al. 2011). Changes in annual nutrient concentrations were recently assessed by Bouraoui \& Grizzetti (2011) for a number of European rivers. The authors also found mixed increasing and decreasing patterns for nitrate and a more general decline for phosphorus and ammonium, yet some discrepancies are found with regard to specific rivers (i.e., the Seine and the Rhone). Differences are likely related to the fact that we compute $\mathrm{TN}$ and not only $\mathrm{NO}_{3}{ }^{-}$, and most importantly, we analyze monthly fluxes and not average annual nutrient concentrations. For phosphorus, there has been a widespread reduction of terrestrial inputs over the past few decades and, in most cases, the P-ICEP today is negative. Negative P-ICEP values point out a deficit of $\mathrm{P}$ with respect to $\mathrm{Si}$ (always considering the Redfield ratio as the reference value) and emphasize the increasing role of $\mathrm{P}$ as a potential limiting nutrient (Peñuelas et al. 2011).

Regulation policies aiming at reducing nutrient inputs to fresh and marine waters flourished in Europe after the 1990s (e.g., the Nitrates Directive, Directive 91/676/EEC; the Urban Waste Water Treatment Directive, Directive 91/271/EEC; the Water Framework Directive, Directive 2000/60/EC; or the most recent Marine Strategy Directive, Directive 2008/56/ EC). The effect of such regulations on 
$\mathrm{N}$ and $\mathrm{P}$ inputs, however, has been quite unequal, as pointed by our results. This discrepancy is ultimately related to their different sources and environmental pathways. Nitrogen pollution mostly comes from diffuse sources, in particular the use of fertilizers in agriculture and stockbreeding practices, while phosphorus comes largely from point sources, namely domestic waste waters (EEA 2005). The early ban of phosphates in household detergents (e.g., Council Directives 73/404/EEC and 73/405/EEC) and the technical improvements in wastewater treatments plants (WWTPs) have effectively contributed to the P reduction observed here. Nitrogen losses from agricultural soils, however, are more difficult to control, and the efficacy of available regulation measures is frequently much lower than expected (Oenema et al. 2005; Bechmann et al. 2008; Thieu et al. 2010). Nitrogen can be widely transported through runoff to freshwater streams and leach from the soil to groundwater reservoirs, where residence times can be long. Consequently, even if present $\mathrm{N}$ inputs to soils were lower than those of past years, $\mathrm{N}$ abatements in rivers could not be apparent until several years or decades later (Ledoux et al. 2007; Bouraoui \& Grizzetti 2011).

The drop of $\mathrm{P}$ inputs in coastal waters has had a direct effect on the phytoplankton biomass. In the Seine Bay, our case-study, regardless of many other interacting factors (the morphology of the coastal area, prevailing currents, tide intensity, etc.), the decrease of $\mathrm{P}$ matches a significant decrease in summer chlorophyll concentrations. The result could be extensive in many other areas, in particular in Mediterranean waters where $\mathrm{P}$ is traditionally considered the main nutrient limiting coastal plankton (Thingstad et al. 1998; Thingstad et al. 2005).

The decline of phytoplankton biomass is a positive sign, albeit a similar direct connection with algal blooms or toxic episodes is hard to find. Indeed, a number of phytoplankton species can be responsible for harmful blooms and the concentration threshold above which we consider it an $\mathrm{HAB}$ and/or a toxic event can vary depending on the organism involved. Such complex patterns may require the inclusion of extra variables, i.e., irradiance, salinity or turbulence, to adequately foresee the outbreaks (Cugier et al. 2005; Lancelot et al. 2009). In any case, it appears that $\mathrm{P}$ abatements alone are not enough to control the noxious episodes in the Seine Bay. Further, the increasing imbalance between N, P and Si may aggravate the situation and trigger more frequent, more toxic or longer-lasting blooms (e.g., Granéli \& Flynn 2006; Conley et al. 2009; Roelke \& Pierce 2011 and references therein).

The persistent $\mathrm{N}$ disproportion is one of the reasons why future management efforts should mainly aim at reducing nitrogen inputs. Further removal of phosphorus compounds is technically possible, although expensive, in WWT facilities (e.g., Chouyyok et al. 2010), yet in view of the present results it may not be enough to keep the problem in check. Apart from inducing coastal eutrophication, high nitrate concentrations in freshwater systems pose a serious risk to drinking water supplies, because 
they can contaminate both surface waters and shallow aquifers. Most of the drinking water production would then require either a denitrification treatment or drawing water from deeper aquifers, which would increase its cost. Challenging as it may be, the step forward should therefore imply a reduction of nitrogen inputs (Paerl 2009); given that the EU Urban Waste Water Treatment Directive (Directive 91/271/EEC) has already been implemented in most European countries, the efforts ought to focus on land management and likely new agricultural practices (Oenema et al. 2011; Grizzetti et al. 2011).

\section{CONCLUSIONS}

We provide data on nutrient export for 28 rivers in southwestern Europe and analyze long-term changes in the context of anthropogenic pressures and regulation policies. Special attention is given to seasonal variations, because the integrated annual values that are usually provided do not allow establishing comparisons with seasonal phytoplankton dynamics. Broadly, there have been considerable phosphorus reductions in most southwestern European rivers during the past decade, whereas $\mathrm{N}$ inputs show nonuniform trends, e.g., there is an increase in the English Channel but a slight decrease in the Mediterranean Sea. Nonetheless, nitrogen is largely in excess over silica in most of the river systems studied.

We synthesize the eutrophication risk associated with river inputs by means of an index (ICEP, Billen \& Garnier 2007) and offer an overview on its temporal evolution and intra-annual variability. Analyzing the annual dynamics of the eutrophication index is very interesting because it allows us to delimit those periods when the risk of eutrophication is particularly high.

We compare this index of eutrophication potential with real phytoplankton data from the Seine Bay. The decrease in P-ICEP matches a general decrease of phytoplankton biomass in the summer. However, sustained high values of N-ICEP may still foster the emergence of harmful algal blooms and we found an increase in the summer abundance of dinoflagellates. Changes in riverine nutrient fluxes are likely to affect coastal phytoplankton, yet direct, causal links are difficult to determine because alternative factors, such as increasing temperatures or changes in turbulence and stratification, may also play a role in the biomass shifts observed.

The abatement of $\mathrm{P}$ alone is not enough to shortcut harmful blooms and toxic outbreaks in the Seine Bay. Further connections with environmental conditions and a reduction in $\mathrm{N}$ inputs may be necessary to effectively minimize eutrophication problems. Additional studies with phytoplankton data from other parts of Europe are envisaged to allow better comparisons between coastal sites with high ICEPs and the frequency of blooms or toxic episodes. 


\section{ACKNOWLEDGEMENTS}

The Federation Ile-de-France for Research on the Environment (FIRE FR3020 CNRS \& UPMC) is acknowledged for the CNRS post-doc grant provided to Estela Romero and for the interdisciplinary research framework provided during this study. Luis Lassaletta was funded by an Exchange Grant of the "Nitrogen in Europe: Assessment of current problems and future solutions" (NinE) program (European Science Foundation) and a research post-doc grant from the Paris City Council (Research in Paris). The study was funded by the French project NEREIS (GIP-Seine Aval, http://seineaval.crihan.fr/web/), by the FP7 European AWARE project (http://www.aware-eu.net/) and by the French project PASTEK (GIS-Climat, http://www.gisclimat.fr/). We are grateful to the national water authorities in France, Spain, Italy, Portugal and Belgium for kindly providing data on river flow and water quality. We are also grateful to the IFREMER for providing valuable information on coastal phytoplankton. The RHLN network is funded by the Agence de l'Eau Seine Normandie and the Région Basse Normandie. We thank B. Grizzetti for kindly reviewing the manuscript and for the useful comments and suggestions. We are grateful to the two anonymous reviewers for their constructive and useful comments.

\section{REFERENCES}

Amzil Z, Royer F, Sibat M, Fiant L, Gelin M, Le Gal D, Françoise S (2007) First report on amnesic and diarrhetic toxins detection in French scallops during 2004- 05 monitoring surveys. Proceedings of the 6th International Conference on Molluscan Shellfish Safety: 307-314

Anderson DM, Burkholder JM, Cochlan WP, Glibert PM, Gobler CJ, Heil CA, Kudela RM, Parsons ML, Rensel JEJ, Townsend DW, Trainer VL, Vargo GA (2008) Harmful algal blooms and eutrophication: Examining linkages from selected coastal regions of the United States. Harmful Algae 8(1): 39-53

Anderson DM, Glibert PM, Burkholder J M (2002) Harmful algal blooms and eutrophication: Nutrient sources, composition, and consequences. Estuaries 25(4B): 704-726

Andreu J, Ferrer-Polo J, Perez MA, Solera A (2009) Decision support system for drought planning and management in the J ucar River basin, Spain. 18th World IMACS / MODSIM Congress: 3223-3229

Arnell NW (1999) The effect of climate change on hydrological regimes in Europe: a continental perspective. Global Environmental Change-Human and Policy Dimensions 9(1): 5-23

Barceló D, Sabater S (2010) Water quality and assessment under scarcity: prospects and challenges in Mediterranean watersheds. J ournal of Hydrology 383(1-2): 1-4

Bechmann M, Deelstra J, Stalnacke P, Eggestad HO, Oygarden L, Pengerud A (2008) Monitoring catchment scale agricultural pollution in Norway: policy instruments, implementation of mitigation methods and trends in nutrient and sediment losses. Environmental Science \& Policy 11(2): 102-114

Belin C, Beliaeff B, Raffin B, Rabia M, Ibanez F (1995) Phytoplankton time-series data of the French phytoplankton monitoring network: toxic and dominant species. In: Lassus P, Arzul G, Erard Le Denn E, 
Gentien P, Marcaillou Le Baut C (Eds.), Harmful marine algal blooms - Proliférations d'algues marines nuisibles. Paris-France Lavoisier, pp. 771- 776

Billen G, Garnier J (2007) River basin nutrient delivery to the coastal sea: assessing its potential to sustain new production of non-siliceous algae. Marine Chemistry 106(1-2): 148-160

Billen G, Garnier J, Ficht A, Cun C (2001) Modeling the response of water quality in the Seine river estuary to human activity in its watershed over the last 50 years. Estuaries 24(6B): 977-993

Bouraoui F, Grizzetti B (2011) Long term change of nutrient concentrations of rivers discharging in European seas. Science of the Total Environment 409(23): 4899-4916

Bouraoui F, Grizzetti B, Aloe A (2010) Estimation of water fluxes into the Mediterranean Sea. Journal of Geophysical Research-Atmospheres 115, D21116, doi: 10.1029/2009J D013451

Chouyyok W, Wiacek RJ, Pattamakomsan K, Sangvanich T, Grudzien RM, Fryxell GE, Yantasee W (2010) Phosphate Removal by Anion Binding on Functionalized Nanoporous Sorbents. Environmental Science \& Technology 44(8): 3073-3078

Cloern JE (2001) Our evolving conceptual model of the coastal eutrophication problem. Marine Ecology-Progress Series 210: 223-253

Conley DJ , Carstensen J , Aertebjerg G, Christensen PB, Dalsgaard T, Hansen J LS, J osefson AB (2007) Long-term changes and impacts of hypoxia in Danish coastal waters. Ecological Applications 17(5): S165-S184

Conley DJ, Paerl HW, Howarth RW, Boesch DF, Seitzinger SP, Havens KE, Lancelot C, Likens GE (2009) Controlling Eutrophication: Nitrogen and Phosphorus. Science 323(5917): 1014-1015

Conley DJ, Schelske CL, Stoermer EF (1993) Modification of the biogeochemical cycle of silica with eutrophication. Marine Ecology-Progress Series 101(1-2): 179-192

Crouzet P, Nixon S, Rees Y, Parr W, Laffon L, Bogestrand J, Kristensen P, Lallana C, Izzo G, Bokn T, Bak J, Lack TJ, Thyssen N (1999) Nutrients in European Ecosystems. Environmental Assessment report 4, EEA, Copenhagen, 155 pp.

Cugier P, Billen G, Guillaud JF, Garnier J, Ménesguen A (2005) Modelling the eutrophication of the Seine Bight (France) under historical, present and future riverine nutrient loading. J ournal of Hydrology 304(1-4): 381396

Diaz RJ , Rosenberg R (2008) Spreading dead zones and consequences for marine ecosystems. Science 321(5891): 926-929

Directive 73/404/EEC on the approximation of the laws of the Member States relating to detergents, OJ L 347, 17/ 12/ 1973, pp. 51- 52

Directive 73/405/EEC on the approximation of the laws of the Member States relating to methods of testing the biodegradability of anionic surfactants, OJ L 347, 17/ 12/ 1973, pp. 53-63

Directive 91/271/EEC concerning urban waste-water treatment, OJ L 135, 30/5/ 1991, pp. 40- 52

Directive 91/676/EEC concerning the protection of waters against pollution caused by nitrates from agricultural sources, OJ L 375, 31/ 12/ 1991, pp. 1-8

Directive 2000/60/EC of the European Parliament and of the Council establishing a framework for the Community action in the field of water policy, OJ L 327, 22/ 12/2000, pp. 1- 73 
Directive 2008/56/EC of the European Parliament and of the Council establishing a framework for community action in the field of marine environmental policy (Marine Strategy Framework Directive), OJ L 164, 25/6/2008, pp. 19-40

European Environment Agency, EEA (2001) Eutrophication in Europe's coastal waters. Topic Report 7/2001, 86 pp., ISBN 92-9167-401-X

European Environment Agency, EEA (2002) Testing of indicators for the marine and coastal environment in Europe. Part 1: Eutrophication and integrated coastal zone management. Technical Report 84, 48 pp., ISBN 92-9167-502-4

European Environment Agency, EEA (2005) Source apportionment of nitrogen and phosphorus inputs into the aquatic environment. EEA Report no. 7/2005, 48 pp., ISBN 92-9167-777-9

European Environment Agency, EEA (2010) The European environment - State and Outlook 2010 (SOER 2010, www.eea.europa.eu/soer). ISBN 978-92-9213-163-0, doi: 10.2800/60214

Estrela, T., Menéndez, M., Dimas, M., Marcuello, C., Rees, G., Cole, G., Weber, K., Grath, J., Leonard, J., Ovesen, N.B., Fehér, J., Consult, V. (2001) Sustainable water use in Europe - Part 3: Extreme hydrological events: floods and droughts. Environmental issue report No. 21, EEA, Copenhagen, 84 pp.

Ferreira JG, Andersen JH, Borja A, Bricker SB, Camp J, da Silva MC, Garcés E, Heiskanen A-S, Humborg C, Ignatiades L, Lancelot C, Ménesguen A, Tett P, Hoepffner N, Claussen U (2011) Overview of eutrophication indicators to assess environmental status within the European Marine Strategy Framework Directive. Estuarine Coastal and Shelf Science 93(2): 117-131

Garnier J, Beusen A, Thieu V, Billen G, Bouwman L (2010) N:P:Si nutrient export ratios and ecological consequences in coastal seas evaluated by the ICEP approach. Global Biogeochemical Cycles 24, GB0A05. doi: 10.1029/2009GB003583

Garnier J, Sferratore A, Meybeck M, Billen G, Dürr H (2006) Modeling silicon transfer processes in river catchments. In: Ittekkot V, Unger D, Humborg C, Tac An N (Eds.), The Silicon Cycle. SCOPE Report 66, Island Press, Washington DC, pp. 139- 162

Glibert PM, Allen J I, Bouwman AF, Brown CW, Flynn KJ , Lewitus AJ, Madden CJ (2010) Modeling of HABs and eutrophication Status, advances, challenges. J ournal of Marine Systems 83(3-4): 262-275

Granéli E, Flynn KJ (2006) Chemical and physical factors influencing toxin content. In: Granéli E, Turner J (Eds.), Ecology of Harmful Algae. Springer, Heidelberg, pp.229- 241

Grizzetti B, Bouraoui F, Aloe A (2012) Changes of nitrogen and phosphorus loads to European seas. Global Change Biology. doi: 10.1111/j.1365-2486.2011.02576.x

Grizzetti B, Bouraoui F, Billen G, van Grinsven H, Cardoso AC, Thieu V, Garnier J, Curtis C, Howarth R, J ohnes P (2011) Nitrogen as a threat to European water quality. In: Sutton MA, Howard CM, Erisman JW, Billen G, Bleeker A, Grennfelt P, van Grinsven H, Grizzetti B (Eds.), The European Nitrogen Assessment. Sources, effects and policy perspectives. Cambridge University Press, pp. 379-404

Guillaud JF, Ménesguen A (1998) Modelling over twenty years (1976-1995) of the phytoplanktonic production in the Bay of Seine. Oceanologica Acta 21(6): 887-906

Hirsch RM, Slack JR, Smith RA (1982) Techniques of trend analysis for monthly water quality data, Water Resources Research 18 (1): 107- 121. doi: 10.1029/WR018i001p00107 
Hodgkins GA, Dudley RW (2006) Changes in the timing of winter-spring streamflows in eastern North America, 1913-2002. Geophysical Research Letters 33(6), L06402. doi: 10.1029/2005GL025593

Humborg C, Conley DJ, Rahm L, Wulff F, Cociasu A, Ittekkot V (2000) Silicon retention in river basins: Farreaching effects on biogeochemistry and aquatic food webs in coastal marine environments. Ambio 29(1): 4550

Humborg C, Pastuszak M, Aigars J, Siegmund H, Morth CM, Ittekkot V (2006) Decreased silica land-sea fluxes through damming in the Baltic Sea catchment - significance of particle trapping and hydrological alterations. Biogeochemistry 77(2): 265-281

Ibáñez C, Prat N, Duran C, Pardos M, Munné A, Andreu R, Caiola N, Cid N, Hampel H, Sánchez R, Trobajo R (2008) Changes in dissolved nutrients in the lower Ebro river: causes and consequences. Limnetica 27(1): 131142

J ørgensen BB, Richardson K (1996) Eutrophication in coastal marine ecosystems. American Geophysical Union, Washington, DC

Justić D, Rabalais NN, Turner RE, Dortch Q (1995) Changes in Nutrient Structure of River-Dominated Coastal Waters - Stoichiometric Nutrient Balance and Its Consequences. Estuarine, Coastal and Shelf Science 40(3): 339-356

Kemp WM, Boynton WR, Adolf JE, Boesch DF, Boicourt WC, Brush G, Cornwell J C, Fisher TR, Glibert PM, Hagy JD, Harding LW, Houde ED, Kimmel DG, Miller WD, Newell RIE, Roman MR, Smith EM, Stevenson JC (2005) Eutrophication of Chesapeake Bay: historical trends and ecological interactions. Marine EcologyProgress Series 303: 1-29

Kudela RM, Lane JQ, Cochlan WP (2008) The potential role of anthropogenically derived nitrogen in the growth of harmful algae in California, USA. Harmful Algae 8(1): 103-110

Lancelot C (1995) The mucilage phenomenon in the continental coastal waters of the North Sea. Science of the Total Environment 165(1-3): 83-102

Lancelot C, Rousseau V, Gypens N (2009) Ecologically based indicators for Phaeocystis disturbance in eutrophied Belgian coastal waters (Southern North Sea) based on field observations and ecological modelling. J ournal of Sea Research 61(1-2): 44-49

Lancelot C, Spitz Y, Gypens N, Ruddick K, Becquevort S, Rousseau V, Lacroix G, Billen G (2005) Modelling diatom and Phaeocystis blooms and nutrient cycles in the Southern Bight of the North Sea: the MIRO model. Marine Ecology-Progress Series 289: 63-78

Lassaletta L, García-Gómez H, Gimeno BS, Rovira JV (2009) Agriculture-induced increase in nitrate concentrations in stream waters of a large Mediterranean catchment over 25 years (1981-2005). Science of the Total Environment 407(23): 6034-6043

Lassaletta L, Romero E, Billen G, Garnier J, García-Gómez H, Rovira JV (2012) Spatialized N budgets in a large agricultural Mediterranean watershed: high loading and low transfer. Biogeosciences 9: 57-70. doi: $10.5194 /$ bg- $9-57-2012$

Ledoux E, Gomez E, Monget J M, Viavattene C, Viennot P, Ducharne A, Benoit M, Mignolet C, Schott C, Mary B (2007) Agriculture and groundwater nitrate contamination in the Seine basin. The STICS-MODCOU modelling chain. Science of the Total Environment 375(1-3): 33-47 
Lefebvre A, Guiselin N, Barbet F, Artigas FL (2011) Long-term hydrological and phytoplankton monitoring (19922007) of three potentially eutrophic systems in the eastern English Channel and the Southern Bight of the North Sea. ICESJ ournal of Marine Science 68(10): 2029-2043

Lehner B, Henrichs T, Döll P, Alcamo J (2001) EuroWasser - Model-based assessment of European water resources and hydrology in the face of global change. Chapter 5: Europe's water stress today and in the future. Kassel World Water Series 5, Center for Environmental Systems Research, University of Kassel, Germany

Libiseller C (2004) MULTMK/ PARTMK - A program for the computation of multivariate and partial MannKendall tests. Department of Mathematics, Linköping University, Sweden

Ludwig W, Bouwman AF, Dumont E, Lespinas F (2010) Water and nutrient fluxes from major Mediterranean and Black Sea rivers: Past and future trends and their implications for the basin-scale budgets. Global Biogeochemical Cycles 24, GB0A13. doi: 10.1029/2009GB003594

Ludwig W, Dumont E, Meybeck M, Heussner S (2009) River discharges of water and nutrients to the Mediterranean and Black Sea: Major drivers for ecosystem changes during past and future decades? Progress in Oceanography 80(3-4): 199-217

Ludwig W, Meybeck M, Abousamra F (2003) Riverine transport of water, sediments, and pollutants to the Mediterranean Sea. UNEP-MAP Technical report Series 141, UNEP/MAP Athens, 111 pp.

Metzger MJ , Bunce RGH, van Eupen M, Mirtl M (2010) An assessment of long term ecosystem research activities across European socio-ecological gradients. J ournal of Environmental Management 91(6): 1357-1365

Milliman JD (2001) Delivery and fate of fluvial water and sediment to the sea: a marine geologist's view of European rivers. Scientia Marina 65: 121-131

Mimikou MA, Kanellopoulou SP, Baltas EA (1999) Human implication of changes in the hydrological regime due to climate change in Northern Greece. Global Environmental Change-Human and Policy Dimensions 9(2): $139-156$

Monbet Y (1992) Control of phytoplankton biomass in estuaries - a comparative-analysis of microtidal and macrotidal estuaries. Estuaries 15(4): 563-571

Montresor M, Smetacek V (2002) The impact of harmful algal blooms in natural and human-modified systems of northern Europe. In: Wefer G, Berger W, Behre K-E \&J ansen E (eds) Climate development and history of the North Atlantic Realm. Springer-Verlag, Heidelberg. p 457-471

Némery J, Garnier J, Morel C (2005) Phosphorus budget in the Marne Watershed (France): urban vs. diffuse sources, dissolved vs. particulate forms. Biogeochemistry 72(1): 35-66

Oenema O, Bleeker A, Braathen NA, Budnakova M, Bull K, Cermak P, Geupel M, Hicks K, Hoft R, Kozlova N, Leip A, Spranger T, Valli L, Velthof G, Winiwarter W (2011) Nitrogen in current European policies. In: Sutton MA, Howard CM, Erisman JW, Billen G, Bleeker A, Grennfelt P, van Grinsven H, Grizzetti B (Eds.), The European Nitrogen Assessment. Sources, effects and policy perspectives. Cambridge University Press, pp. 62- 81

Oenema O, van Liere L, Schoumans O (2005) Effects of lowering nitrogen and phosphorus surpluses in agriculture on the quality of groundwater and surface water in the Netherlands. J ournal of Hydrology 304(14): 289-301

Officer CB, Ryther JH (1980) The Possible Importance of Silicon in Marine Eutrophication. Marine EcologyProgress Series 3(1): 83-91 
OSPAR (1998) Principles of the comprehensive study on riverine inputs and direct discharges (RID). OSPAR Commission, Reference number: 1998-5, 17 pp.

OSPAR (2003) Integrated report on the eutrophication status of the OSPAR maritime area based upon the first application of the Comprehensive Procedure. OSPAR Commission, Eutrophication Series, 59 pp., ISBN 1904426-25-5

Paerl HW (2009) Controlling Eutrophication along the Freshwater-Marine Continuum: Dual Nutrient (N and P) Reductions are Essential. Estuaries and Coasts 32(4): 593-601

Pekarova P, Miklanek P, Pekar J (2003) Spatial and temporal runoff oscillation analysis of the main rivers of the world during the 19th-20th centuries. J ournal of Hydrology 274(1-4): 62-79

Pekarova P, Miklanek P, Pekar J (2006) Long-term trends and runoff fluctuations of European rivers. In: Demuth S, Gustard A, Planos E, Scatena F, Servat E (Eds) Climate Variability and Change - Hydrological Impacts, Proceedings of the 5th FRIEND World Conference. IAHS Publication, Havana, Cuba. pp. 520-525

Peñuelas J, Sardans J , Rivas A, J anssens IA (2011) The human induced imbalance between C, N and P in Earth's lifesystem. Global Change Biology. doi: 10.1111/j.1365-2486.2011.02568.x

Rabalais NN, Turner RE, Diaz RJ, Justić D (2009) Global change and eutrophication of coastal waters. ICES J ournal of Marine Science 66(7): 1528-1537

Rabouille C, Conley DJ, Dai MH, Cai WJ, Chen CTA, Lansard B, Green R, Yin K, Harrison PJ, Dagg M, McKee B (2008) Comparison of hypoxia among four river-dominated ocean margins: The Changjiang (Yangtze), Mississippi, Pearl, and Rhone rivers. Continental Shelf Research 28(12): 1527-1537

Redfield AC (1934) On the proportions of organic derivatives in sea water and their relation to the composition of plankton. In: J ames J ohnstone Memorial Volume, University Press of Liverpool, pp. 176- 192

Redfield AC, Ketchum BH, Richards FA (1963) The influence of organisms on the composition of seawater. In: Hill MN (Ed.), The composition of seawater. Comparative and descriptive oceanography. The sea: ideas and observations on progress in the study of the seas II, pp. 26- 77

Roelke DL, Pierce RH (2011) Effects of inflow on harmful algal blooms: some considerations. J ournal of Plankton Research 33(2): 205-209

Schoemann V, Becquevort S, Stefels J, Rousseau W, Lancelot C (2005) Phaeocystis blooms in the global ocean and their controlling mechanisms: a review. J ournal of Sea Research 53(1-2): 43-66

Sferratore A, Garnier J , Billen G, Conley DJ , Pinault S (2006) Diffuse and point sources of silica in the Seine river watershed. Environmental Science \& Technology 40(21): 6630-6635

Smayda TJ (1990) Novel and nuisance phytoplankton blooms in the sea: evidence for a global epidemic. In: Granéli E, Sundström B, Edler R, Anderson DM (Eds.) Toxic Marine Phytoplankton. Elsevier, New York, pp. $29-40$

Tett P, Gilpin L, Svendsen H, Erlandsson CP, Larsson U, Kratzer S, Fouilland E, Janzen C, Lee J-Y, Grenz C, Newton A, Gomes Ferreira J, Fernandes T, Scory S (2003) Eutrophication and some European waters of restricted exchange. Continental Shelf Research 23: 1635- 1671

Thieu V, Garnier J, Billen G (2010) Assessing the effect of nutrient mitigation measures in the watersheds of the Southern Bight of the North Sea. Science Of The Total Environment 408(6): 1245-1255

Thingstad F, Billen G (1994) Microbial-degradation of Phaeocystis material in the water column. Journal of Marine Systems 5(1): 55-65 
Thingstad TF, Krom MD, Mantoura RFC, Flaten GAF, Groom S, Herut B, Kress N, Law CS, Pasternak A, Pitta P, Psarra S, Rassoulzadegan F, Tanaka T, Tselepides A, Wassmann P, Woodward EMS, Wexels Riser C, Zodiatis G, Zohary T (2005) Nature of Phosphorus Limitation in the Ultraoligotrophic Eastern Mediterranean. Science 309: 1068-1071

Thingstad TF, Zweifel UL, Rassoulzadegan F (1998) P limitation of heterotrophic bacteria and phytoplankton in the northwest Mediterranean. Limnology and Oceanography 43(1): 88-94

Verhoff FH, Melfi DA, Yaksich SM (1980) River nutrient and chemical transport estimation. J ournal of the Environmental Engineering Division 106 (3): 591-608

Videau C, Ryckaert M, L'Helguen S (1998) Phytoplankton in the Bay of Seine (France). Influence of the river plume on primary productivity. Oceanologica Acta 21(6): 907-921

Vila M, Camp J, Garcés E, Masó M, Delgado M (2001) High resolution spatio-temporal detection of potentially harmful dinoflagellates in confined waters of the NW Mediterranean. J ournal of Plankton Research 23(5): 497-514

Walling DE, Webb BW (1985) Estimating the discharge of contaminants to coastal waters by rivers: some cautionary comments. Marine Pollution Bulletin 16(12): 488-492

Wriedt G, van der Velde M, Aloe A, Bouraoui F (2009) A European irrigation map for spatially distributed agricultural modelling. Agricultural Water Management 96(5): 771-789

Yu YS, Zou SM, Whittemore D (1993) Non-parametric trend analysis of water-quality data of rivers in Kansas. J ournal of Hydrology 150(1): 61-80 